\title{
UM BOSQUE DE FOLHAS SAGRADAS: O SANTUÁRIO NACIONAL DA UMBANDA E O CULTO DA NATUREZA
}

A GROVE OF SACRED LEAVES: THE NATIONAL SANCTUARY OF UMBANDA AND THE WORSHIP OF NATURE

\begin{abstract}
Autores
Matheus Colli Silva. Mestrando. Universidade de São Paulo, Instituto de Biociências, Departamento de Botânica.

E-mail: matheus.colli.silva@alumni.usp.br

Vagner Gonçalves da Silva Professor. Universidade de São Paulo, Faculdade de Filosofia, Letras e Ciências Humanas, Departamento de Antropologia.

E-mail: vagnergo@usp.br
\end{abstract}

Recebido em: 21/01/2019 Aprovado em: 31/01/2019

DOI: $10.12957 /$ interag. 2018.39594

\section{Artigo}

O Santuário Nacional da Umbanda, localizado na Região Metropolitana de São Paulo, é um espaço de Mata Atlântica reivindicado e recuperado pelos seus frequentadores. É reservado às práticas rituais dos adeptos das religiões afro-brasileiras, sobretudo da umbanda, onde as entidades estão diretamente associadas aos elementos naturais. Com base em um trabalho etnográfico (observação de campo e entrevistas) realizado com frequentadores do Santuário, analisamos as características do conhecimento religioso associado aos significados das plantas cultuadas, bem como o acesso a esse material e a importância da existência do Santuário. Foram mencionados 64 tipos de plantas cultuadas, sendo grande parte delas componente da cultura popular brasileira, e que possuem um sistema de classificação baseado em pares de oposição que corresponde à lógica do pensamento

\section{Abstract}

The "Santuário Nacional da Umbanda" (National Sanctuary of Umbanda), located in the Metropolitan Region of São Paulo state, is an area of Atlantic Forest recovered and demarked for ritual practices of Afro-Brazilian religions, especially "umbanda", whose entities are directly associated with natural elements. Based on an ethnographic work (field observation and interviews) carried out with the Sanctuary visitors, we analyzed the characteristics of the religious knowledge associated with the meaning of the worshiped plants and importance of the Sanctuary. A total of 64 different types of plants were mentioned, most of them from the Brazilian popular culture. They have a classification system based on opposition pairs that corresponds to the logic of the Umbandist thinking. Interviews show how the conceptions of nature, energy, entities and conservation are 
umbandista. Os relatos mostram como as concepções de natureza, energia, entidades e conservação estão interligadas. Para os frequentadores, o Santuário também é visto como um lugar para o culto sagrado da umbanda, diante dos problemas contemporâneos como violência e intolerância religiosa. O processo de urbanização dificultou a relação dos umbandistas com a natureza e o acesso às ervas; daí o anseio da comunidade pela existência de um espaço natural íntegro, sagrado e acolhedor, ainda que uma natureza "construída" para o culto.

Palavras- chave: Religiões afrobrasileiras; Rituais religiosos; Conservação da natureza; Natureza/ cultura.

Área Temática: Meio ambiente Linha Temática: Questões ambientais; Cultura. interconnected. For the visitors, the Sanctuary is also seen as a place for the sacred cult of umbanda, in face of contemporary issues such as violence and religious intolerance. The urbanization process made it difficult for Umbandists to relate to nature and access many worshiped herbs. Therefore, religious community longs for the maintenance of this a healthy, sacred and welcoming natural space, albeit a nature "built" for worship.

Keywords: Afro-Brazilian religions; Religious rituals; Conservation of nature; Nature/culture.

\section{Introdução}

As religiões afro-brasileiras, apesar de toda a sua diversidade, podem ser genericamente descritas como resultantes do encontro de povos europeus, africanos e indígenas. A umbanda, em particular, como religião tipicamente urbana que nasceu no final do século XIX, combina elementos de religiões espíritas europeias, como o kardecismo (religião espírita criada na França e trazida ao Brasil por Allan Kardec), com elementos do candomblé e do catolicismo ${ }^{1,2}$. Consequentemente, a umbanda herda também valores associados a essas religiões, como a caridade, o respeito à natureza, a eternidade de espírito, a empatia e a liberdade 3 . Ou seja, ela pode ser entendida como uma forma religiosa que "preservou a concepção kardecista do carma, da evolução espiritual e da comunicação com os espíritos", mas que, por outro lado "mostrou-se aberta às formas populares do culto africano"3 (p. 112). Daí, além das entidades africanas (i.e., os orixás), consagra-se também espíritos que enaltecem os povos "fundadores" do Brasil; de maneira que a figura do negro passa a ser representada pelos espíritos dos pretos-velhos e a do índio pelos espíritos dos caboclos, por exemplo.

Nessas religiões, é comum associar diferentes ervas ou folhas a diferentes entidades ou espíritos. Muitos são os orixás, e cada um possui o seu domínio; aqueles mais associados ao domínio da mata são Oxóssi, Ossaim ou Ogum, onde o sincretismo com os elementos vegetais é óbvio ${ }^{3,4}$. Mas mesmo outros orixás que ocupam domínios como o da água (lemanjá, Oxum) ou do fogo (Exu, lansã) possuem sempre pelo menos uma erva 
associada ${ }^{3,4}$. Ou seja, o papel dos elementos vegetais é nuclear na consolidação e manutenção dessas religiões, bem como de seus valores. E isso foi algo particularmente potencializado no Brasil, que é o país mais rico em número de espécies de plantas do mundo 5 .

No candomblé, vários estudos mostram o emprego litúrgico ou medicinal de muitas plantas, onde há um sistema de classificação complexo, além de uma intrincada relação entre as entidades, a energia espiritual (denominada "axé") e os diferentes elementos vegetais $^{3,4,6}$. No entanto, essa relação na umbanda ainda não está muito bem esclarecida e deve ser melhor explorada ${ }^{7}$. De qualquer forma, certamente o culto das entidades, tanto na umbanda como no candomblé, torna-se bastante dificultado num contexto de cidade, onde há restrição de espaços naturais em detrimento do crescimento desordenado dos espaços urbanos ${ }^{8}$. Consequentemente, as religiões afro-brasileiras desenvolvem-se num contexto tipicamente urbano, elaborando estratégias para a carência de folhas sagradas e de espaços naturais, que se encontram cada vez mais restritos às unidades de conservação, mananciais ou áreas marginais cujo desmatamento é legalmente proibido. Por fim, há ainda aqueles pontos remanescentes que não foram alcançados pelas transformações decorrentes do processo de urbanização.

No entanto, a religião pode ainda "criar" ou sacralizar espaços onde a natureza prevaleça, ainda que uma natureza "construída" para o culto, como é o caso do "Vale dos Orixás", em Juquitiba, e do "Santuário Nacional da Umbanda" (SANU), em Santo André. Ambos são espaços no estado de São Paulo que recriam, na cidade, o "bosque sagrado" presente nas regiões africanas de onde vieram as fontes constitutivas das religiões afro-brasileiras. O SANU em particular é um espaço reivindicado e mantido pela comunidade umbandista do ABC Paulista, ou seja, da região que compreende os municípios de São Caetano do Sul, Santo André, São Bernardo, Mauá, Ribeirão Pires, Diadema e Rio Grande da Serra. O Santuário ocupa uma área de cerca de 645 mil metros quadrados de uma antiga pedreira que já era utilizada pelos umbandistas desde os anos de 1970 e que posteriormente foi cedida em regime de comodato pela prefeitura do município de Santo André. O SANU localiza-se dentro de uma unidade de conservação que compreende uma extensa área de Mata Atlântica restaurada principalmente pela ação dos próprios frequentadores, que percebem a vegetação como sagrada, e tomam medidas de conservação, criando hábitos que ajudam a preservar esse espaço.

Ou seja, o estudo em prol do (re)conhecimento de espaços reivindicados por ação popular e sacralizados, bem como da importância dos elementos naturais que os permeiam vem sendo cada vez mais urgente num planeta onde o espaço geográfico tende a ser rapidamente modificado. Além disso, o estudo das religiões afro-brasileiras é importante no sentido de valorizar uma cultura que historicamente vêm sofrendo uma série de ataques e que socialmente é marginalizada9. Tendo isso em mente, o objetivo deste trabalho é fazer uma análise dos fatores associados à natureza, espiritualidade e ervas utilizadas no contexto da umbanda, utilizando como modelo de estudo o espaço do SANU. Propõe-se apresentar um histórico do Santuário, a importância desse espaço para a prática umbandista em São Paulo e a necessidade de se manter uma vegetação íntegra para o culto. Isso servirá de subsídio para uma discussão sobre os usos religiosos das plantas na umbanda, além de trazer aspectos sobre o padrão de uso e consumo dos elementos vegetais nas religiões afro-brasileiras em São Paulo. 


\section{Metodologia}

A metodologia do trabalho consistiu em duas abordagens complementares: (1) revisão bibliográfica sobre os trabalhos que abordam o tema do uso dos vegetais na umbanda e no candomblé, bem como do histórico do SANU; e (2) trabalho de campo, com realização de entrevistas e observação participante.

O levantamento bibliográfico consistiu no acesso à literatura de etnobotânica e sobre as religiões afro-brasileiras (ver referências). Além disso, também foi realizada uma síntese das informações com relação ao histórico e funcionamento do SANU, acessando tanto documentos oficiais (planos de manejo, laudos técnicos) como reportagens e publicações referentes ao Santuário, sobretudo aqueles disponibilizados pela equipe administradora do SANU.

Com relação ao trabalho de campo, foram entrevistadas treze lideranças de terreiros oriundas de oito templos umbandistas das regiões mais díspares da Região Metropolitana de São Paulo e que frequentam o espaço do Santuário (Figura 1). As entrevistas ocorreram entre o período de julho e outubro de 2017. Como quatro das oito entrevistas foram realizadas com mais de uma pessoa ao mesmo tempo, formaram-se oito grupos de entrevistados (Tabela 1). Sete dos oito grupos tinham também seus terreiros próprios, e um era formado por duas pessoas que já possuíram um terreiro, mas que hoje não mais o possuem. Optou-se por priorizar entrevistar pessoas que tinham um longo histórico de frequência no Santuário e que fossem as principais representantes dos terreiros (i.e., mães ou pais-de-santo, mães-pequenas). Essas pessoas foram indicadas pela equipe da administração do Santuário, que detém os contatos dos frequentadores e que gentilmente os ofereceu após entrar em contato com cada um dos entrevistados, informando- Ihes do propósito da pesquisa e convidando-os a participarem da mesma.

As entrevistas foram de caráter semiestruturado, e seguiram um roteiro que se encontra em material suplementar (Tabela S1). O roteiro versa basicamente sobre questões relacionadas ao simbolismo religioso associado à vegetação do Santuário como um todo, bem como sobre informações mais específicas a respeito das plantas usadas no cotidiano umbandista e sobre a importância da prática dos rituais num espaço natural íntegro e zelado. A maioria das entrevistas foi realizada nos terreiros-sede e/ou nas residências das lideranças (caso as mesmas não tivessem uma sede fixa). Duas entrevistas foram realizadas no próprio espaço do Santuário, onde lá também foi realizada observação participante de algumas atividades, como seções de trabalho de ervas, de atendimento ou "passe", seções de incorporação ou trabalhos de homenagem a entidades. Fotografias foram retiradas e áudios das entrevistas foram gravados e depois transcritos, para então serem analisados comparativamente.

A partir das transcrições, as falas dos entrevistados foram sistematizadas em uma tabela (Tabela S2, em material suplementar), procurando classificar as falas com relação à concepção de natureza, das entidades e de energia, bem como a relação entre o indivíduo, a entidade, o Santuário e a natureza. Do produto desta análise comparativa, algumas falas que representam a opinião geral uma determinada questão foram selecionadas para aqui serem citadas. 
Tabela 1. Síntese das lideranças religiosas e localizações das entrevistas realizadas no período entre julho e outubro de 2017. FMD: Fabiana D. e Márcia D.; RCA: Pai Rafael; MAN: Mãe Rosângela e Márcia; JUP: Mãe Jupira; ANT: Mãe Antônia; SHY: Mãe Shirley; RRA: Roberta, Antônia e Pai Ricardo; DAS: Mãe Sandra e Diego C.

\begin{tabular}{|c|c|c|c|c|}
\hline Grupo de entrevista & Identificação & Localização do terreiro & Local da entrevista & Data \\
\hline FMD & $\begin{array}{l}\text { Fabiana D. } \\
\text { Márcia D. }\end{array}$ & $\begin{array}{l}\text { Não possui sede própria. Reside em Vila Helena, Santo André, SP. } \\
\text { Não possui sede própria. Reside em Vila Helena, Santo André, SP. }\end{array}$ & $\begin{array}{l}\text { Vila Helena, Santo André, SP } \\
\text { Vila Helena, Santo André, SP }\end{array}$ & $7 / 26 / 2017$ \\
\hline$\overline{\text { RCA }}$ & Pai Rafael & Vila Marari, São Paulo, SP & Vila Marari, São Paulo, SP & $8 / 11 / 2017$ \\
\hline MAN & $\begin{array}{l}\text { Mãe Rosângela } \\
\text { Márcia }\end{array}$ & $\begin{array}{l}\text { Butantã, São Paulo, SP } \\
\text { Butantã, São Paulo, SP }\end{array}$ & $\begin{array}{l}\text { Butantã, São Paulo, SP } \\
\text { Butantã, São Paulo, SP }\end{array}$ & $9 / 5 / 2017$ \\
\hline JUP & Mãe Jupira & São Mateus, São Paulo, SP & São Mateus, São Paulo, SP & $9 / 8 / 2017$ \\
\hline$\overline{\text { ANT }}$ & Mãe Antônia & São Mateus, São Paulo, SP & São Mateus, São Paulo, SP & $9 / 29 / 2017$ \\
\hline SHY & Mãe Shirley & Parque Gerassi, Santo André, SP & Parque Gerassi, Santo André, SP & $10 / 9 / 2017$ \\
\hline DAS & $\begin{array}{l}\text { Diego C. } \\
\text { Mãe Sandra }\end{array}$ & $\begin{array}{l}\text { Não possui sede própria. Reside em Guaianases, São Paulo, SP. } \\
\text { Não possui sede própria. Reside em Guaianases, São Paulo, SP. }\end{array}$ & $\begin{array}{l}\text { SANU } \\
\text { SANU }\end{array}$ & $10 / 12 / 2017$ \\
\hline RRA & $\begin{array}{l}\text { Pai Ricardo } \\
\text { Antônia } \\
\text { Roberta }\end{array}$ & $\begin{array}{l}\text { Tucuruvi, São Paulo, SP } \\
\text { Tucuruvi, São Paulo, SP } \\
\text { Tucuruvi, São Paulo, SP }\end{array}$ & $\begin{array}{l}\text { SANU } \\
\text { SANU } \\
\text { SANU }\end{array}$ & $10 / 12 / 2017$ \\
\hline
\end{tabular}

Tabela 1
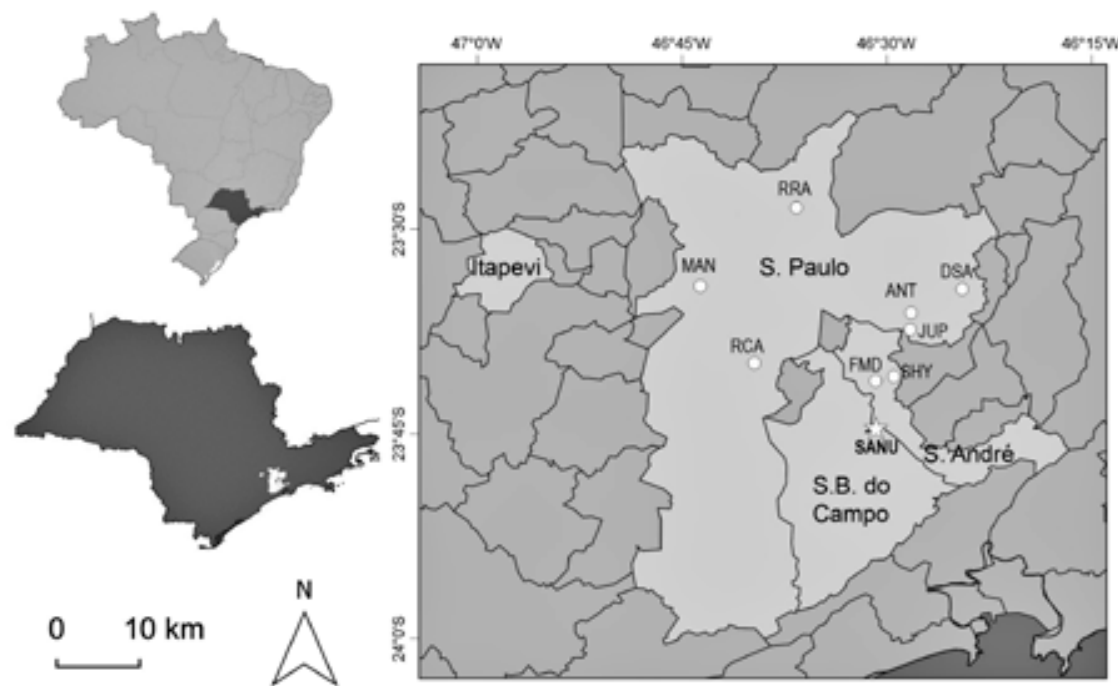

Figura 1 


\section{Material Suplementar}

Um bosque de folhas sagradas: o Santuário Nacional da Umbanda como refúgio ao culto sagrado da natureza

Tabela S1. Roteiro de entrevista semi-estruturada conduzida com lideranças religiosas.

\begin{tabular}{|c|c|}
\hline \multirow{2}{*}{\multicolumn{2}{|c|}{$\begin{array}{l}\text { Título: Roteiro para entrevista semiestruturada } \\
\text { Local de ação: Santuário Nacional do Umbanda, Santo André, SP }\end{array}$}} \\
\hline & \\
\hline \multicolumn{2}{|r|}{$\begin{array}{l}\text { Objetivos gerais: através de observação participante, contatos informais e entrevistas } \\
\text { semiestruturadas, coletar informações sobre espécies de plantas conhecidas no cotidiano da } \\
\text { umbanda, bem como sobre seus usos e significados. Também fazer questões relacionadas ao } \\
\text { simbolismo religioso associado à vegetação como um todo, sua importância para a prática dos } \\
\text { rituais da umbanda e importância para sua conservação e zelo. }\end{array}$} \\
\hline \multicolumn{2}{|c|}{ Identificação da pessoa: } \\
\hline \multicolumn{2}{|c|}{ Nome } \\
\hline \multicolumn{2}{|c|}{ Cargo religioso } \\
\hline \multicolumn{2}{|c|}{ Filho/a de qual orixá ou quais as entidades/linhas que recebe } \\
\hline \multicolumn{2}{|c|}{ Identificação da tenda/terreiro/templo } \\
\hline \multicolumn{2}{|c|}{ Nome } \\
\hline \multicolumn{2}{|r|}{ Endereço: (rua, bairro, cidade) } \\
\hline \multicolumn{2}{|r|}{ Identidade religiosa (como classifica o terreiro: umbanda, candomblé, espiritismo etc.) } \\
\hline \multicolumn{2}{|r|}{ Quais a linhas/entidades que o terreiro cultua } \\
\hline \multicolumn{2}{|c|}{ Significados religiosos das plantas: } \\
\hline 1) & Qual a importância das plantas na prática da sua religião? \\
\hline 2) & Quais as entidades que estão mais associadas à mata? \\
\hline 3) & Qual a importância de se realizar rituais na mata? \\
\hline 4) & Qual a importância do SANU para a prática da sua religião? \\
\hline 5) & $\begin{array}{l}\text { O que você acha da vegetação e das plantas existentes no SANU para a sua prática } \\
\text { religiosa? }\end{array}$ \\
\hline 6) & $\begin{array}{l}\text { Você ou sua entidade utiliza plantas em banhos, chás, remédios etc? Pode dar o nome } \\
\text { de algumas? }\end{array}$ \\
\hline 7) & $\begin{array}{l}\text { Das plantas que você citou, quais partes são utilizadas, de que forma são preparadas e } \\
\text { para qual indicação? São acrescentadas outras plantas? Quais? }\end{array}$ \\
\hline \multirow[t]{2}{*}{ 8) } & As plantas estão associadas as entidades ou linhas (Preto velho, caboclos, exus etc.)? \\
\hline & Por quê? Dar exemplos. \\
\hline 9) & $\begin{array}{l}\text { Como você costuma obter esses materiais vegetais? Se coleta, tem algum período } \\
\text { específico de coleta ou idade da planta? Usado fresco ou seco, em floração ou não? }\end{array}$ \\
\hline
\end{tabular}

\section{Tabela S1}




\begin{tabular}{|c|c|c|c|c|}
\hline \multirow{9}{*}{ 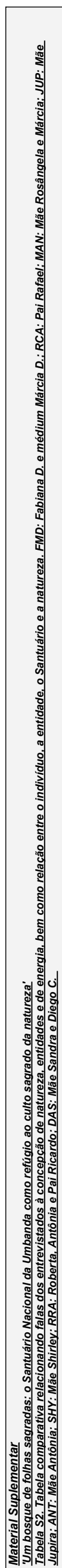 } & 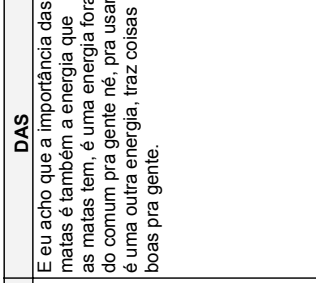 & & & 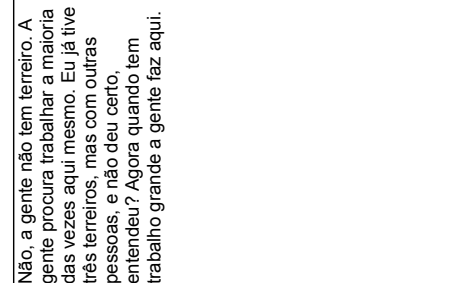 \\
\hline & 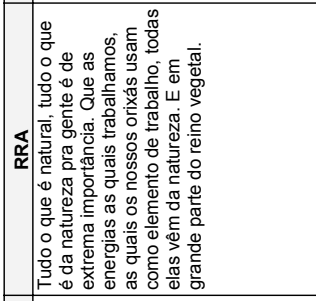 & 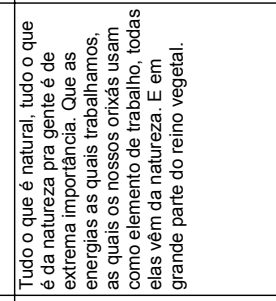 & 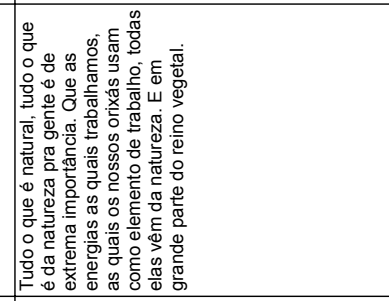 & 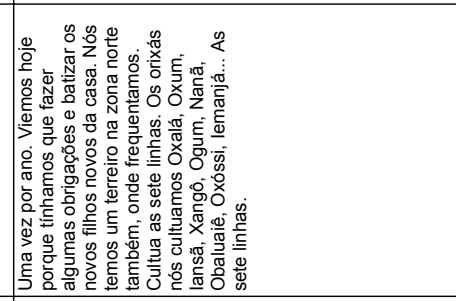 \\
\hline & 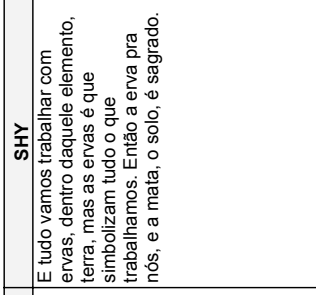 & 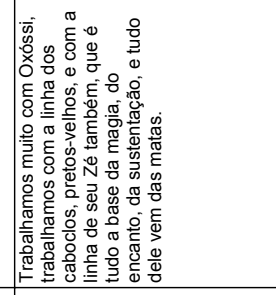 & 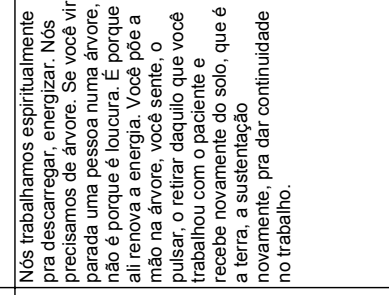 & 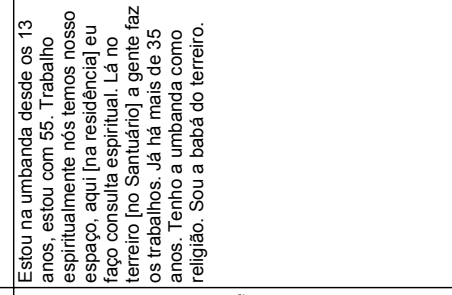 \\
\hline & 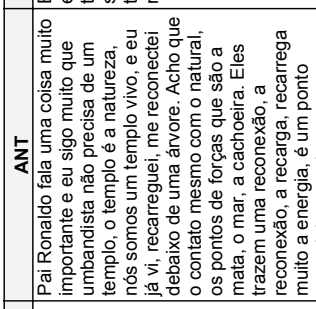 & 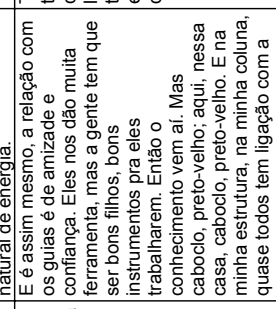 & 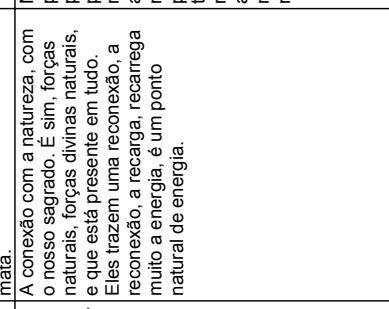 & 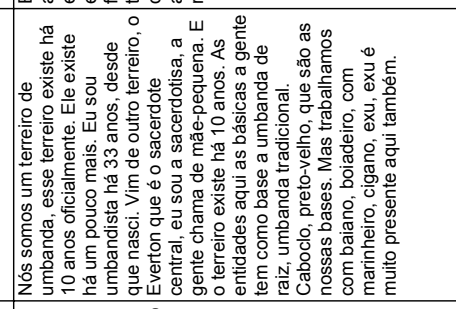 \\
\hline & 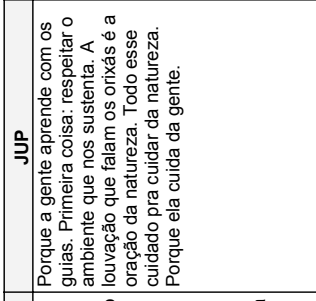 & 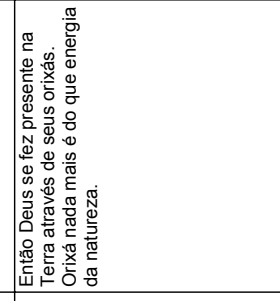 & 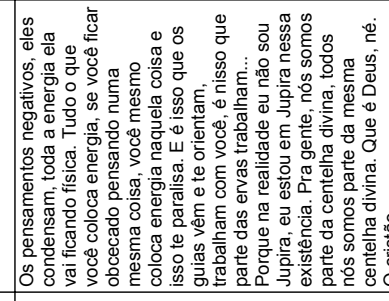 & 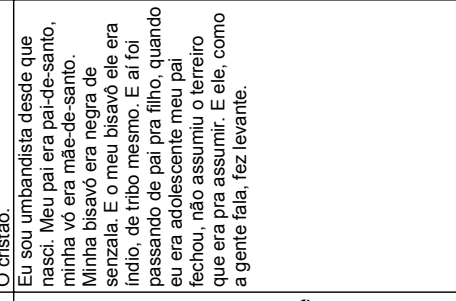 \\
\hline & 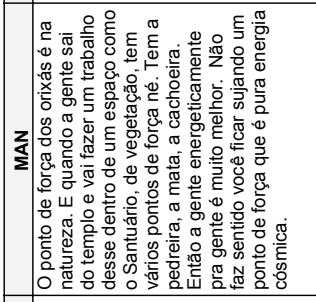 & 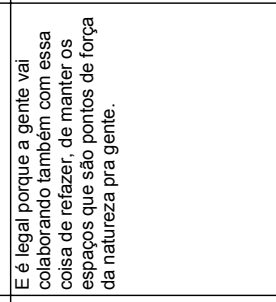 & 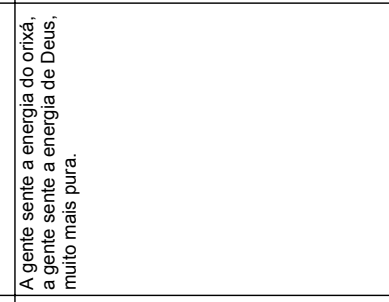 & 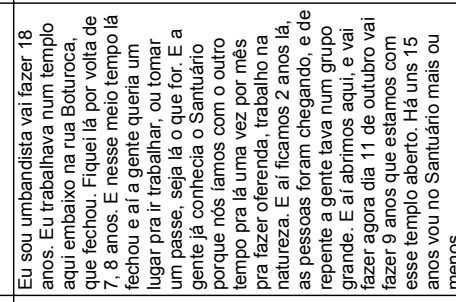 \\
\hline & 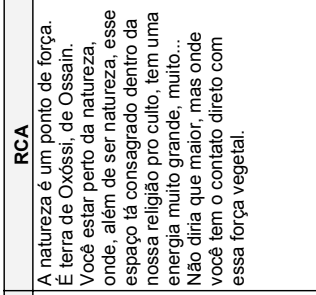 & 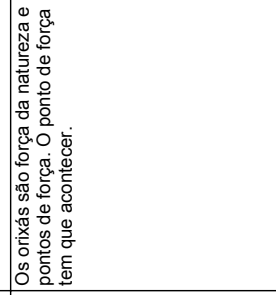 & 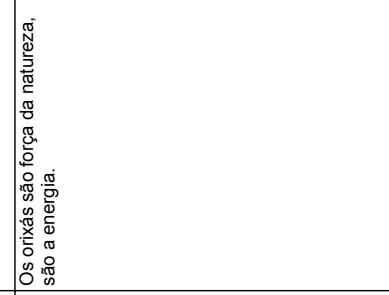 & 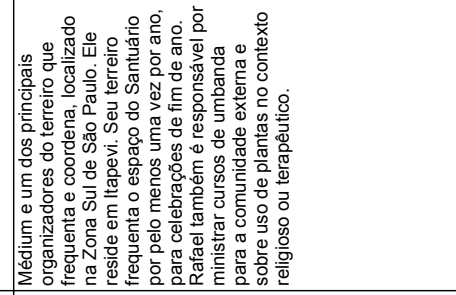 \\
\hline & 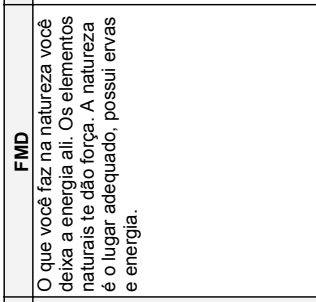 & 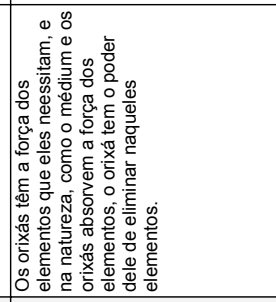 & & 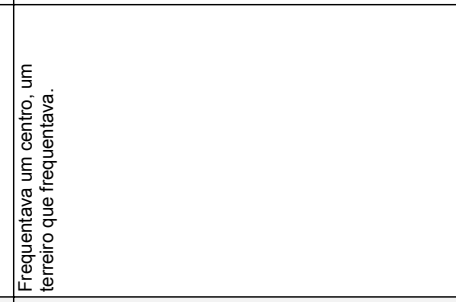 \\
\hline & 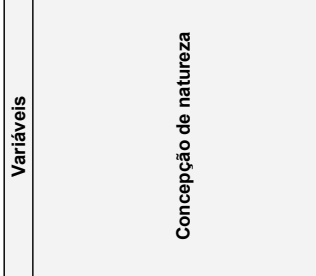 & 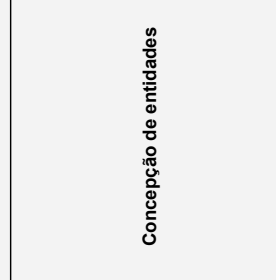 & 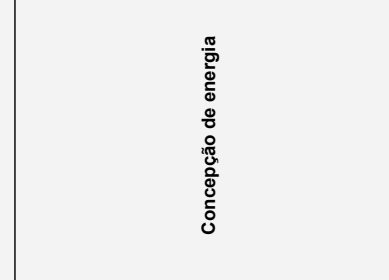 & 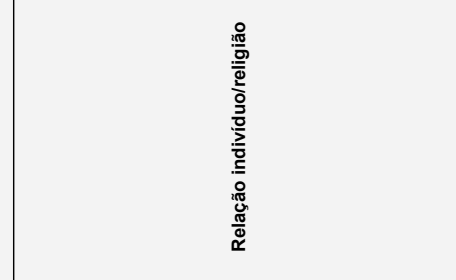 \\
\hline
\end{tabular}




\begin{tabular}{|c|c|c|c|}
\hline 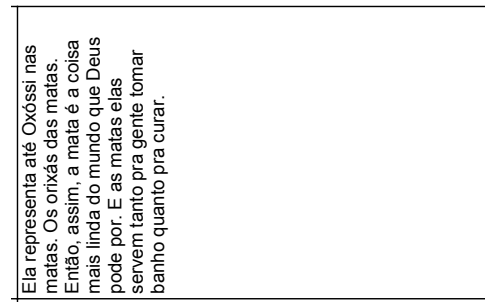 & 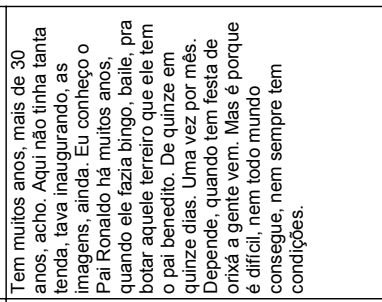 & 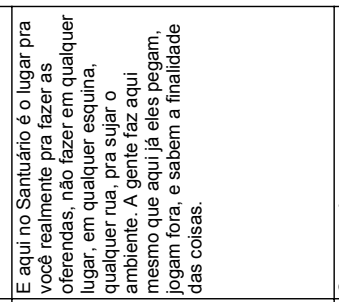 & 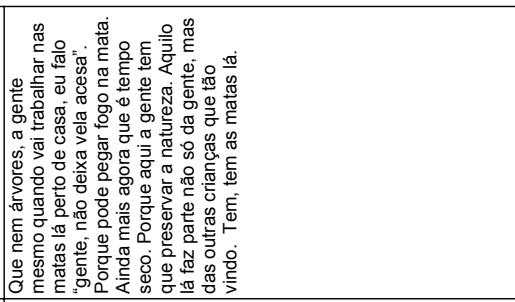 \\
\hline & 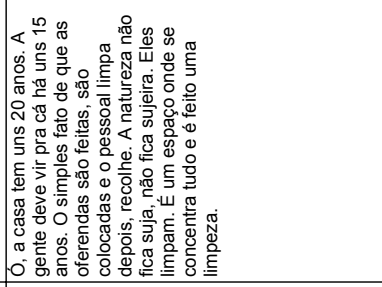 & & \\
\hline 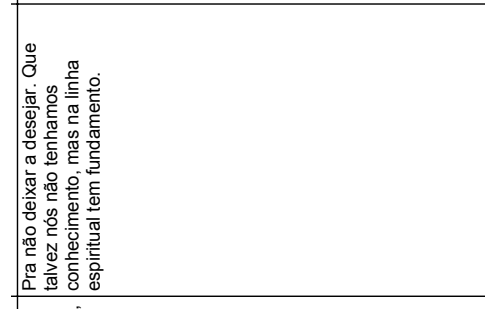 & & 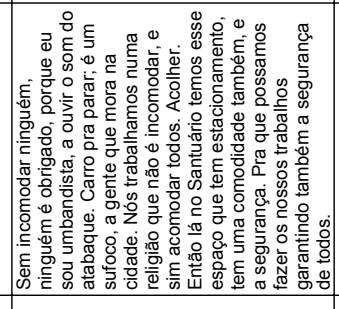 & \\
\hline 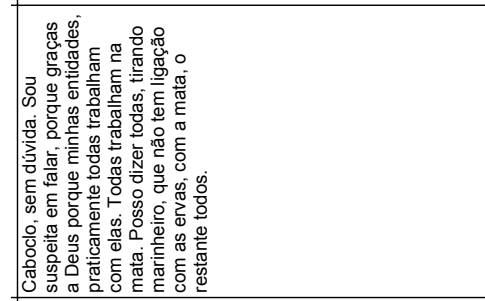 & 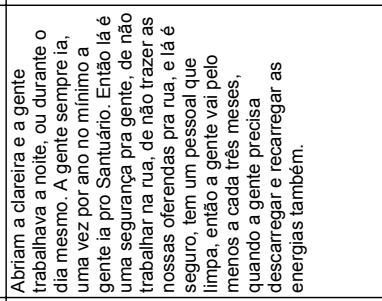 & & \\
\hline 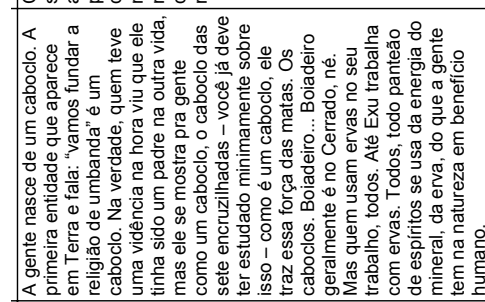 & 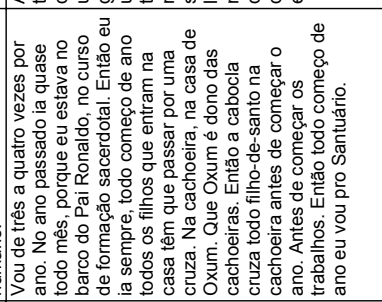 & 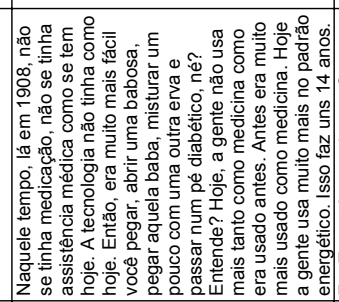 & 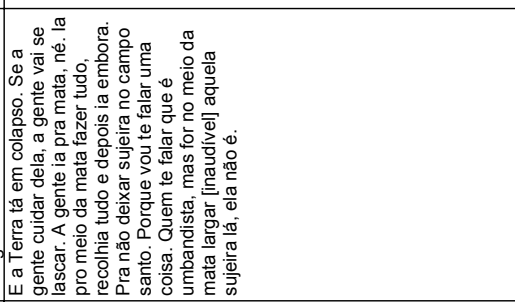 \\
\hline & 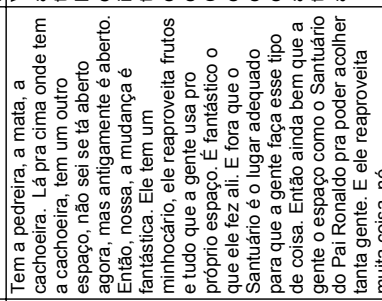 & 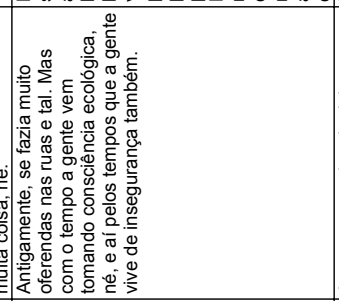 & 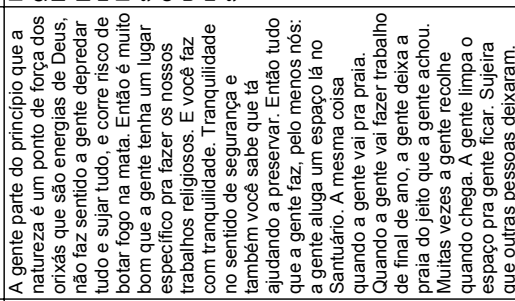 \\
\hline 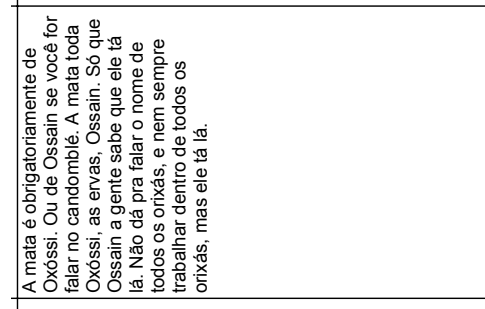 & 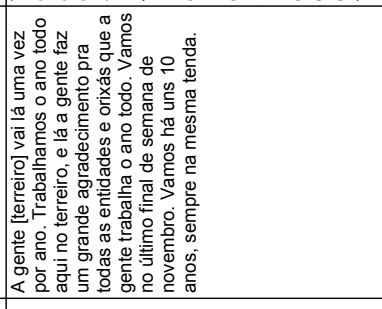 & 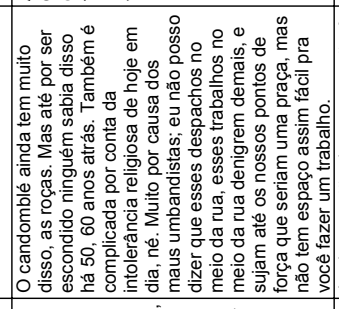 & 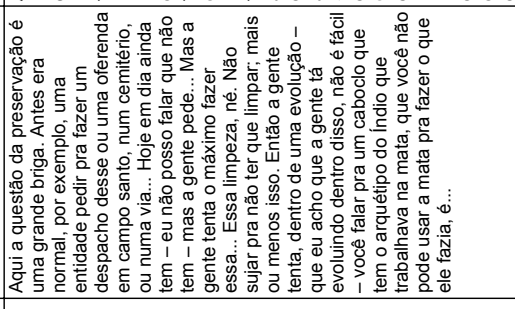 \\
\hline & 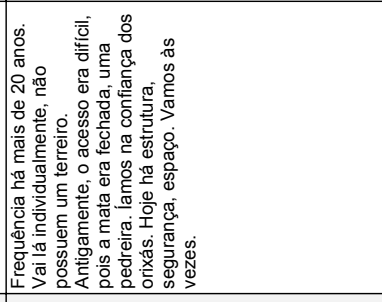 & 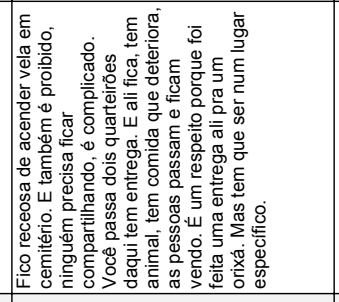 & \\
\hline 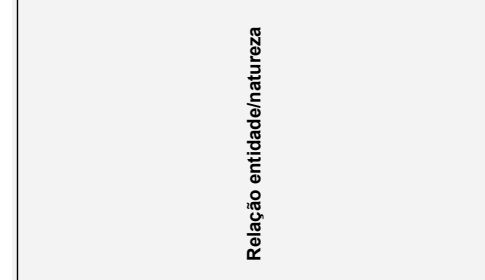 & 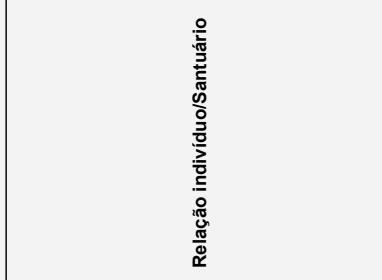 & 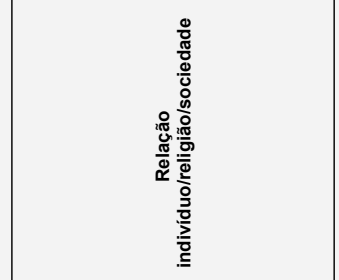 & 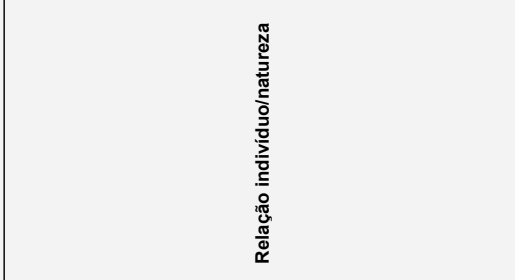 \\
\hline
\end{tabular}




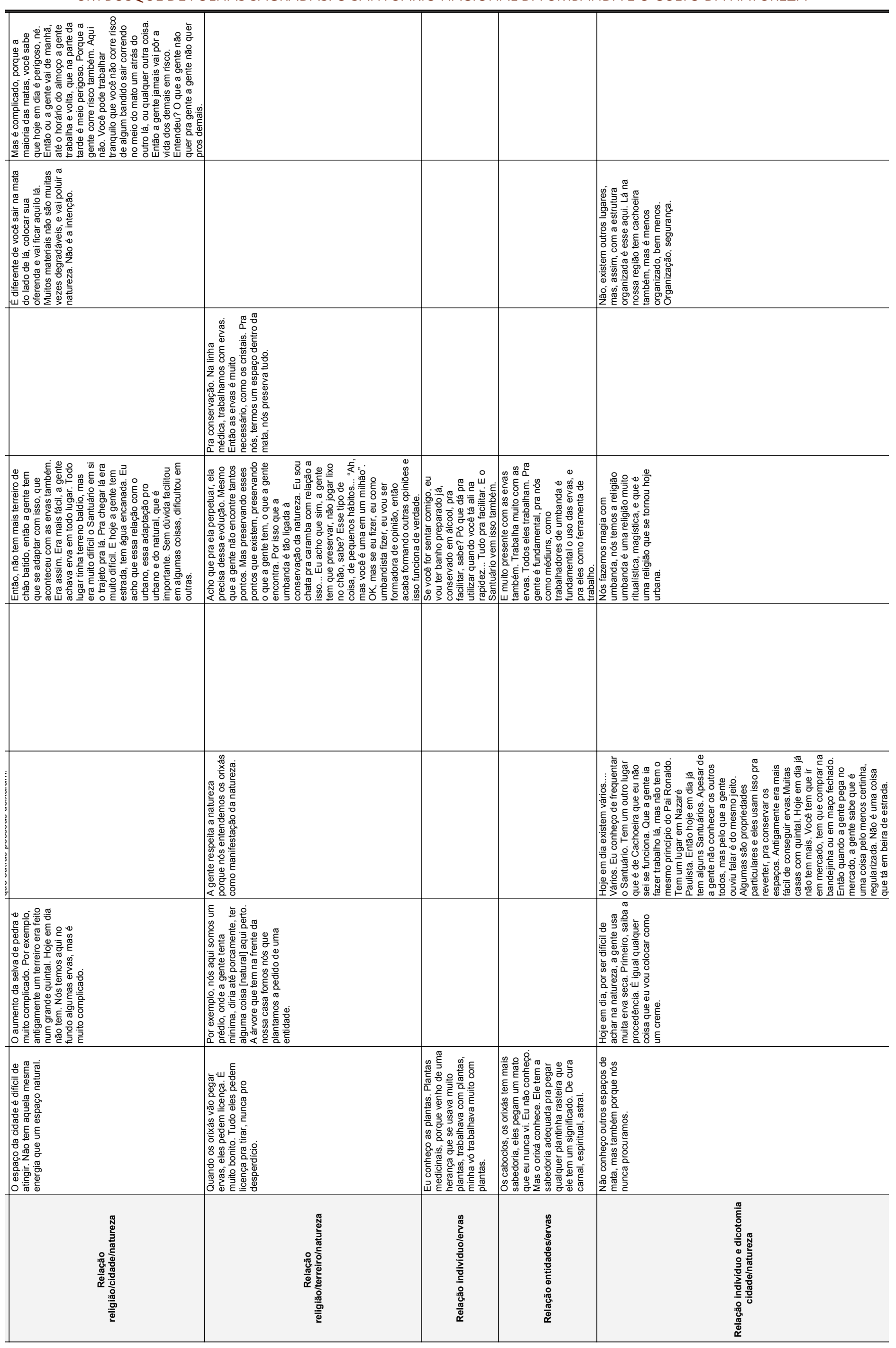



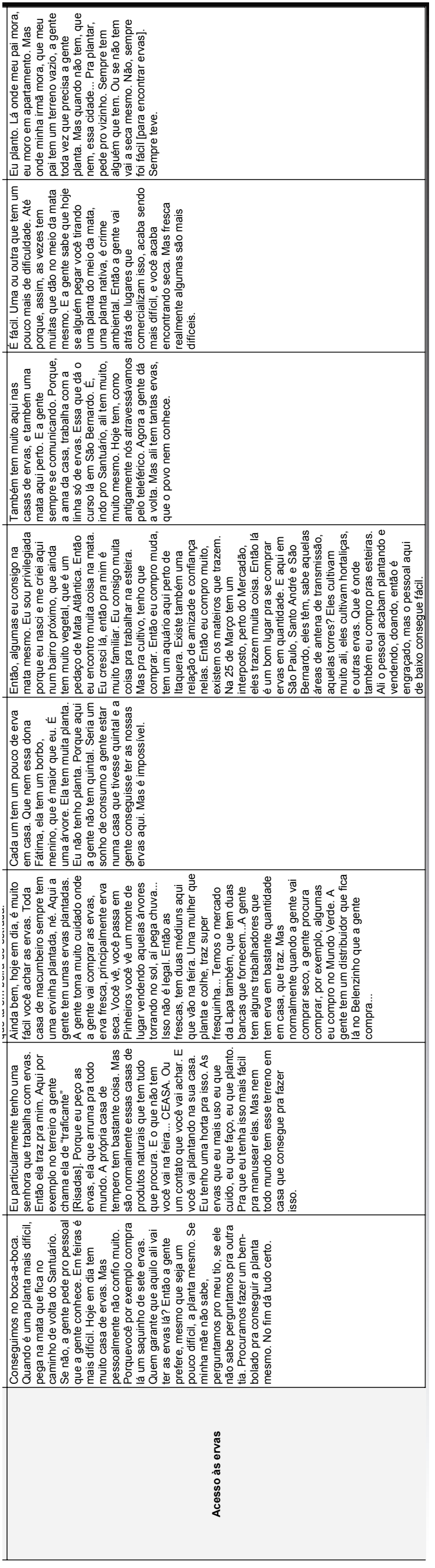

Tabela S2 


\section{Constituindo um "bosque sagrado"}

No SANU, os terreiros podem solicitar à Federação Umbandista do Grande ABC, entidade que administra o local, um espaço demarcado no Santuário onde os rituais são realizados. Muitos espaços são cobertos e possuem altares com imagens de santos católicos e entidades afro-brasileiras (Figura 2). Terreiros sem sede podem também se beneficiar desta área.

A existência institucionalizada de um "bosque sagrado" para a religião também apresenta vantagens em termos de conforto, tranquilidade e segurança, pois, como dizem os religiosos, está cada vez mais difícil de ir a lugares ermos para a realização de rituais sem correr o risco de assaltos e outras formas de violência. Aqui há uma fala de Mãe Shirley, que desenvolve trabalhos espirituais em sua residência há pelo menos 35 anos, onde faz consultas espirituais. Mãe Shirley "trabalha" (ou seja, realiza rituais) com as linhas sagradas da umbanda. Ela frequenta o Santuário desde a sua fundação, e diz:

"Sem incomodar ninguém; ninguém é obrigado, porque eu sou umbandista, a ouvir o som do atabaque. (...) Nós trabalhamos numa religião que não é incomodar, e sim acomodar todos. Acolher. Então lá no Santuário temos esse espaço que tem estacionamento, tem uma comodidade também, e a segurança. Pra que possamos fazer os nossos trabalhos garantindo também a segurança de todos."

No caso das plantas, a possibilidade de coletar folhas e plantar aquelas necessárias ao culto também se verifica. Especialmente no SANU isto se deu, pois, a região ocupada havia sido utilizada para exploração de britas para a construção da Rodovia Anchieta nos anos de 1940. O espaço que estava degradado foi reconstituído pelos religiosos que reflorestaram as encostas dos morros, transformando drasticamente a paisagem do local (Figura 2). A região foi ocupada desde o final do século XIX, sobretudo por colonos italianos que exploraram as reservas naturais, em especial madeira, para ser utilizada na produção de carvão e na indústria moveleira. Após uma intensa atividade de desmatamento na região, percebeu-se o potencial de exploração para produção de pedras para a construção civil e pavimento de estradas, o que deu origem à chamada "Pedreira Montanhão". Dessa forma, após décadas de exploração, o ambiente natural de Mata Atlântica foi pouco a pouco sendo degradado (Figura 2).

A entrevista feita com Pai Ronaldo Linhares, um dos fundadores do Santuário, evidencia a importância sagrada que a mata e os elementos vegetais têm para a umbanda: sempre visto como um espaço puro, intocado e virgem. Pai Ronaldo foi uma figura chave para a consolidação do SANU como "bosque sagrado". Desde o começo da história do Santuário, percebemos a intrincada relação entre a prática religiosa, educação ambiental e restauração e conservação da vegetação ali presente. Diz ele:

"[Antes, éramos grandes destruidores, havia espaços enormes no alto da serra derrubados pela ação dos irmãos de fé. Quando tomei conhecimento disso, pensei em inverter o processo: todo mundo queria uma clareira exclusiva, um espaço exclusivo da mata para sua tenda, que era inerente a quase todos os espaços de umbanda. A lógica era a seguinte: quer uma clareira? Tudo bem; este será seu espaço. Se há mato, não retire; se não há, é obrigado a plantar." 

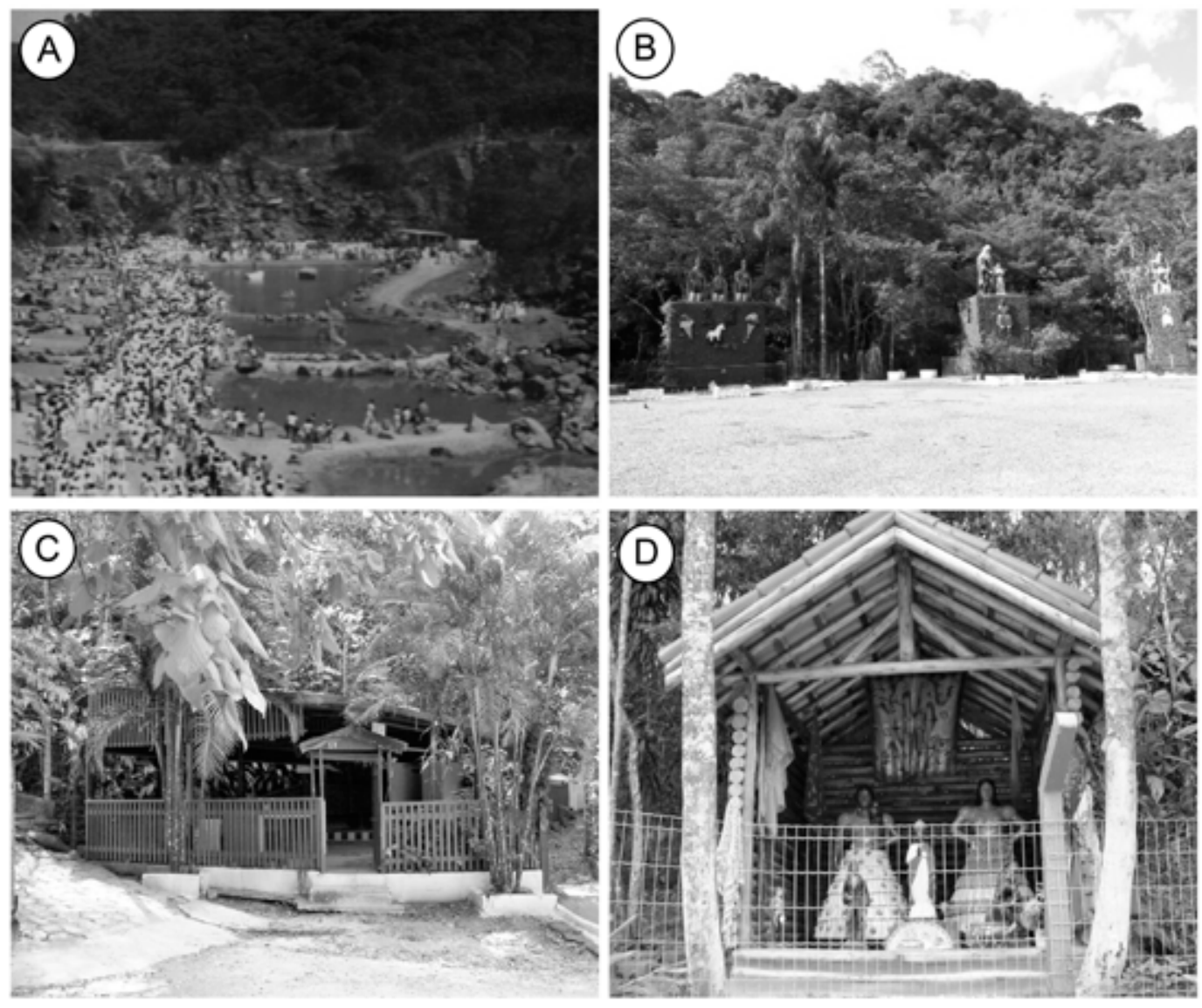

Figura 2

Penoso, intenso e difícil tal como foi o processo de degradação, a restauração ecológica do SANU para aquilo que se observa hoje também demandou muita força de vontade e mão-de-obra. A lógica da restauração, segundo Pai Ronaldo, foi muito baseada nos conhecimentos prévios dos próprios frequentadores:

"Como não tinha vegetação nem recursos para a providência de mudas, um dos simpatizantes tinha um caminhão, e um grupo muito grande voluntariamente ajudava nos finais de semana para reflorestar a região degradada do hoje Santuário. Traziam neste caminhão 200 a 250 sacos vazios, iam ao alto da serra de Paranapiacaba, pegavam material decomposto, folhas mortas, sementes e as colocavam dentro deste saco, levando de volta ao espaço do hoje SANU. Quem os orientou nisso foi a bióloga Egly Joyce, simpatizante do movimento e umbandista. Este material morto era colocado em cima dos espaços que se desejava recuperar, formando um imenso colchão biológico. Há um tempo, aquilo cedia e nasciam diferentes mudas de Mata Atlântica."

As mudas eram conseguidas dos locais mais díspares possíveis, de diferentes espaços da Região Metropolitana de São Paulo. Mesmo tendo realizado o processo de restauração da floresta com relativo sucesso, o espaço do SANU é caracterizado hoje tecnicamente por ser de um bioma florestal secundário dentro do domínio fitogeográfico da Mata Atlântica ${ }^{10}$, com o predomínio de algumas espécies exóticas como eucaliptos, reconhecidas inclusive por Pai Ronaldo como espécies agressivas e não nativas dali. 
A partir da década de 60, o espaço passou então a ser ocupado por esses umbandistas, incluindo Pai Ronaldo, que utilizavam o espaço da pedreira e de matas remanescentes para os seus cultos sagrados, para cultuar sobretudo aquelas entidades associadas à mata ou à pedreira, como Oxóssi e Xangô. A partir dessa relação, começa a nascer a necessidade de se criar um espaço onde se pudesse cultuar as entidades sem incomodar ninguém, mas também sem ser incomodado por ninguém. Em 1979, finalmente houve a oficialização do uso religioso do espaço, que está ativo até hoje.

Apresenta-se aqui uma fala de uma liderança religiosa entrevista que exemplifica a questão da consciência ambiental. Pai Rafael é médium e um dos principais organizadores do terreiro que frequenta na Zona Sul de São Paulo. A comunidade de seu terreiro visita o Santuário ao menos uma vez por ano, para celebrações de fim de ano. Também é responsável por ministrar cursos de umbanda para a comunidade externa sobre o uso de plantas no contexto religioso ou terapêutico. Ele diz:

"Aqui a questão da preservação é uma grande briga. Antes era normal, por exemplo, uma entidade pedir pra fazer um despacho desse ou uma oferenda em campo santo, num cemitério, ou numa via... Hoje em dia ainda tem - eu não posso falar que não tem - mas a gente pede... A gente tenta o máximo fazer essa... Essa limpeza, né. Não sujar pra não ter que limpar; mais ou menos isso. Então a gente tenta, dentro de uma evolução - que eu acho que a gente tá evoluindo dentro disso, não é fácil - você falar pra um caboclo que tem o arquétipo do Índio que trabalhava na mata, que você não pode usar a mata pra fazer o que ele fazia..."

Ou seja, é notável na comunidade umbandista atual uma consciência ambiental que se transpõe para o espectro do sagrado, tal como observa-se tanto na fala de Pai Rafael como na de Pai Ronaldo. O processo oscilante que acompanhou a história do Santuário e o estabelecimento de uma cultura sustentável evidencia isso: muitos esforços se mantêm para não se prejudicar o que se conquistou, de maneira que se observa no Santuário muitas intervenções como avisos indicadores de descarte de resíduos (lixo, cigarros), além de avisos indicando a necessidade de preservação do Santuário, em especial do espaço natural ali presente (Figura 3).
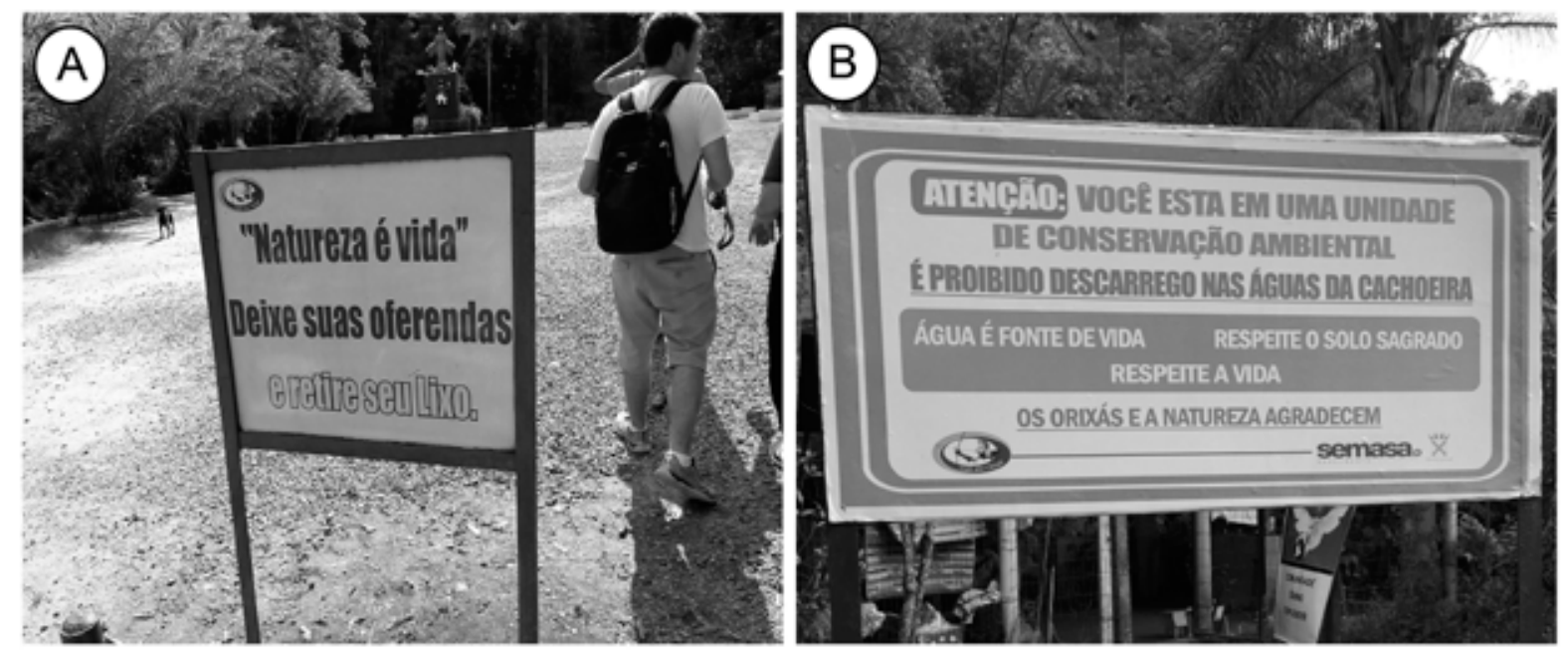

Figura 3 
$\mathrm{Na}$ verdade, é muito comum que os umbandistas se refiram à natureza como "um ponto de força dos orixás"7. Isso porque natureza, energia (ou "axé"), e as entidades são praticamente encarados como sinônimos. Os espaços naturais reconectam e recarregam a energia, pois são elementos das entidades cultuadas. Portanto, tudo que é natural é, para a umbanda, de extrema importância, pois as energias com as quais as entidades trabalham ou usam como ferramenta são oriundas da natureza, e grande parte delas é do reino vegetal. Na umbanda, geralmente Oxóssi e os caboclos são as entidades mais associadas às matas, muito embora a natureza seja um ponto de força de todas as entidades, uma vez que todos, sem exceção, trabalham, de alguma forma, com ervas s,4,11. $^{3}$.

Através dessa manifestação, uma entidade se incorpora numa pessoa que se identifica como médium, e o trabalho mediúnico com as ervas é realizado, seja para descarrego de energias negativas, ou para energização, i.e., atração de energias positivas. Dentro dessa perspectiva, o Santuário vem a ser um espaço que, além de ser sacralizado, é também acolhedor, no sentido de receber e dar suporte para a realização de rituais seguros, sob uma infraestrutura adequada e condições de zelo e conservando a natureza. Essa concepção de natureza, inclusive, recai sobre a fronteira entre a dicotomia que existe na umbanda, uma religião que, apesar de depender diretamente da natureza, é tipicamente uma religião que nasceu e se desenvolveu no ambiente urbano ${ }^{8}$, além de contar com um histórico de intolerância religiosa que limita alguns rituais, como despachos em campos santos (cemitérios, encruzilhadas) ou o sacrifício de animais.

Para exemplificar o acima dito, apresenta-se a fala de mãe Rosângela, que é umbandista há 18 anos e mãe de um terreiro há nove. Ela frequenta o Santuário há pelo menos 15 anos, onde faz visitas anuais, mas que por um tempo, quando ainda não tinha uma sede própria, frequentava o espaço mensalmente:

"A gente parte do princípio que a natureza é um ponto de força dos orixás que são energias de Deus, não faz sentido a gente depredar tudo e sujar tudo, corre o risco de até e botar fogo na mata. Então é muito bom que a gente tenha um lugar específico pra fazer os nossos trabalhos religiosos. E você os faz com tranquilidade. Tranquilidade no sentido de segurança e também que você sabe que tá ajudando a preservar. Então (...), pelo menos nós: a gente aluga um espaço lá no Santuário. A mesma coisa quando a gente vai pra praia. Quando a gente vai fazer trabalho de final de ano, a gente deixa a praia do jeito que a gente achou. Muitas vezes a gente recolhe quando chega. A gente limpa o espaço pra gente ficar, até sujeira que outras pessoas deixaram."

Mais uma vez, nota-se nesta fala a centralidade que a natureza tem como elemento essencial para o culto sagrado da umbanda para os frequentadores do SANU. Apesar dos eventuais conflitos aqui apresentados, tanto por Mãe Rosângela como para Pai Rafael acima, a natureza é, acima de tudo, parte ou o todo da representação de pontos de energia, que são, por sua vez, pontos de força das entidades. Preservar as ervas, a natureza e os espaços naturais é, portanto, preservar a imagem das próprias entidades sagradas. Por isso, é muito comum que haja uma posição em prol da natureza quando se considera a relação da religião com a cidade.

\section{A erva de todo orixá}

O uso de plantas nas religiões afro-brasileiras geralmente é categorizado em três 
grandes sentidos, que não são excludentes, segundo Serra e colaboradores ${ }^{12}$ : (1) uso ritual ou simpático, para atrair alguma necessidade ou desejo; (2) uso alimentar, na forma de oferendas, sobretudo frutas ou outras partes de plantas que representem o orixá ou a divindade que se queira cultuar; e (3) uso terapêutico, para cura ou revitalização, priorizando as folhas em detrimento das ervas. No caso da umbanda em particular, Carlessi ${ }^{7}$ separa quatro tipos diferentes grupos de uso: (1) banhos de ervas, (2) chás e defumações, (3) preparo de fundamentos e (4) trabalhos e oferendas. Para Camargo 6,13 a influência das tradições europeias e indígenas no uso de plantas foi importante para o candomblé, pois as populações africanas e seus descendentes não encontraram no Brasil a mesma flora de suas terras de origem, culminando numa inevitável relação de aproximação com as plantas aqui existentes.

As plantas utilizadas nas oferendas ou como ervas medicinais são sempre em referência alguma entidade ou orixá, de maneira que elas têm a função de renovar a força mágica atribuída aos deuses cultuados, bem como para fortalecê-los simbolicamente ${ }^{1,3,11}$. Cada entidade possui uma oferenda ou erva específica, de acordo com a sua especificidade e função espiritual (Figura 4). A umbanda e o candomblé são uma das religiões que mais possuem rituais com a participação ativa de elementos vegetais; oferecimento de oferendas às entidades implica na assumpção de que as mesmas estão "comendo" as oferendas, garantindo a presença das entidades na vida dos praticantes². Grande parte dessas oferendas são conseguidas através da compra, mas alguns estudos mostram forte presença de atividades de extrativismo ou cultivo em áreas ruderais, antropizadas, até mesmo em alguns espaços realmente naturais, intocados, pois pensa-se que os vegetais empregados nessas religiões devem provir do seu local de origem ${ }^{4,12}$. Além disso, não são quaisquer alimentos que podem ser oferecidos, de maneira que cada orixá possui prescrições e restrições de alimentos de acordo com a história mítica a ele associada ${ }^{12}$.
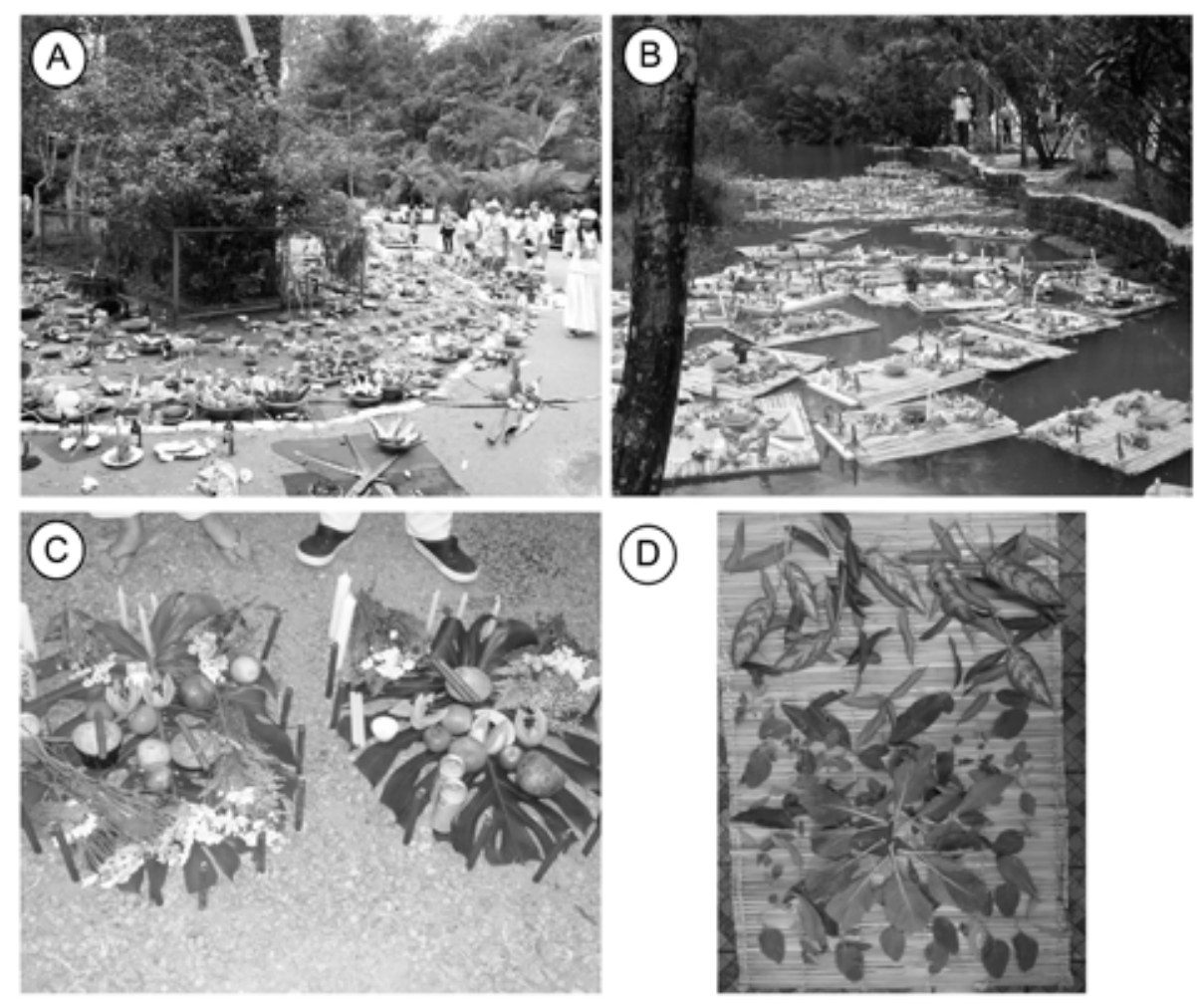

Figura 4 
Especificamente para a umbanda, Carlessi ${ }^{7}$ realizou um trabalho muito interessante, onde demonstrou que grande parte das plantas utilizadas na umbanda são espécies de distribuição ampla no território brasileiro, abundantes, fáceis de serem obtidas, seja porque são comuns na vegetação, seja porque já eram recorrentes na cultura brasileira de uso antes do estabelecimento dessas religiões no país. Nota-se a presença, portanto, de muitas espécies exóticas (isto é, espécies não nativas do Brasil, aqui introduzidas via ação antrópica) ou naturalizadas (e.g. alecrim, Rosmarinus officinalis L. (Lamiaceae); abacateiro, Persea americana Mill (Lauraceae)), nativas de outras regiões da América Latina7,11,14, além de espécies ruderais - i.e., espécie cuja distribuição acompanha a do ser humano - e.g. maria-sem-vergonha, espécies do gênero Impatiens L. (Apocynaceae)) ou mesmo invasoras - i.e., espécie exótica e naturalizada que apresenta altas taxas de reprodução e dispersão, colonizando o ecossistema natural e danificando - (e.g. lírio-do-brejo ou jasmim-do-brejo, Hedychium coronarium J. Koenig (Zingiberaceae)). Plantas que, além de serem utilizadas em rituais, são muitas vezes consideradas como medicinais, mesmo fora do contexto religioso afro-brasileiro $0^{4,6,11,14}$.

Geralmente, Márcia e mãe Shirley citaram plantas mais específicas, utilizadas também em outros contextos, que são incorporadas de outros sistemas culturais, como "algas marinhas", "fiapos do milho", "mirra", "taioba" (Tabela 1). Elas, ao contrário dos demais, fazem parte de uma umbanda mais esotérica, que incorpora muitos elementos da cultura popular e do misticismo popular, inclusive produzindo e comercializando extratos para fins medicinais ou homeopáticos, que, inclusive, é técnico e dependente de uma série de tratamentos e pesagens. Veja o que Márcia diz:

"Então, aí vem aquela velha história. Eles [os orixás] sempre falam pra gente. Como eles fazem, eles ensinam [o intermediário ou ajudante] pra eles ensinarem o médium. Então vou fazer um chá dessa planta. Então eu vou pegar essa planta inteira? Não. Porque na homeopatia e na botânica, tudo é pesado."

Agora, sob um ponto de vista de uma análise qualitativa, há algum indício de haver dependência entre o preparo de chás para plantas exclusivamente medicinais e o preparo de banhos para plantas exclusivamente rituais, embora exista um universo híbrido de plantas que são rituais e medicinais dependendo do contexto (Figura 5). Grande parte das plantas citadas são usadas para banho (49\% de 64 citações), mas há também usos em chás ou como firmezas espirituais (Figura 5). Para algumas plantas, também foram citadas aplicações na forma de emplastos, ou através da defumação de algumas partes vegetais, sobretudo folhas.

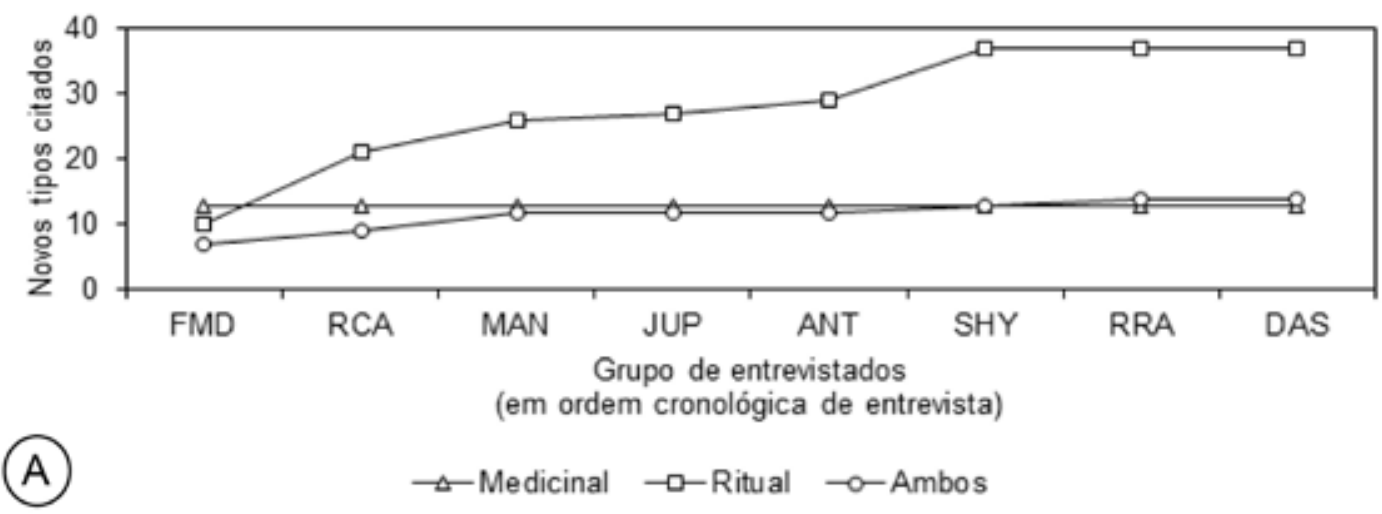




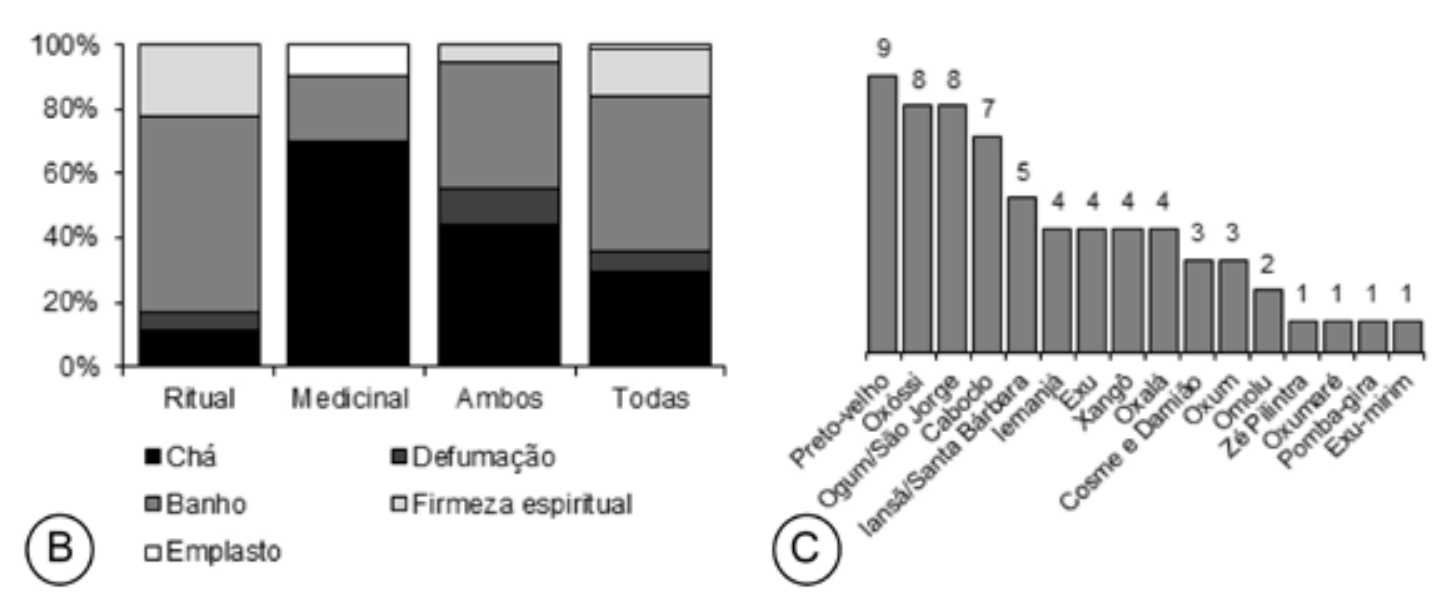

Figura 5

No trabalho das entrevistas, a tendência também é a de preponderar menções de espécies vegetais que muito provavelmente não são nativas do Brasil, mas que, na sua grande maioria, fazem parte da cultura popular do brasileiro porque foram ora trazidas para cá. Há a menção de plantas que são utilizadas amplamente em outros contextos populares (Tabela 1), como plantas alimentícias (abacate, milho, batata-doce), temperos (alecrim, manjericão, canela, cravo, anis-estrelado) ou onde delas se faz chás ou bebidas comuns no dia-a-dia do brasileiro (café, camomila, cana-de-açúcar, boldo). Não são plantas que ocorrem em regiões onde nasceram originalmente essas religiões, i.e., no continente africano"; de fato, nota-se, no Brasil, grande adaptação ou "abrasileiramento", usando-se de um neologismo, da flora utilizada nos rituais afro-brasileiros. Essa adaptação da flora é amplamente observada e discutida no candomblé,711,14,15, e se mostra presente na umbanda para o contexto deste estudo.

Vê-se aqui, portanto, o paralelismo entre o uso de plantas comestíveis convencionais e a prática de rituais, de maneira que muitas plantas tidas como oferendas são derivados de alimentos comuns no Brasil, muitas introduzidas no continente sul-americano e que são recorrentes hoje na cultura brasileira, bem como na cultura urbana do país. Do ponto de vista de distribuição geográfica, a grande maioria dessas plantas são espécies exóticas, cultivadas, que também vão ao encontro da gastronomia e hábitos alimentares do Nordeste do Brasil, sobretudo da Bahia, que tem, assim como todo o país, grande parte das plantas comestíveis oriundas de espécies exóticas, sobretudo devido ao processo de colonização. Como diz Barros ${ }^{16}$ :

"Ao mesmo tempo em que eram desenvolvidos esses dois movimentos [de transação de espécies vegetais] - Brasil-África/África-Brasil, foi sendo efetivado o processo de emprego de plantas comuns aos dois continentes (...). Outras espécies, entretanto, tiveram que ser substituídas, porém as substituições obedeceram ao padrão africano de classificação." (Barros, 1993, pp. 36-37).

Muitas vezes uma mesma erva se circunscreve no domínio de mais de um orixá. De qualquer maneira, a entidade mais citada para as ervas aqui mencionadas foi Preto-VeIho, além de Oxóssi, Ogum/São Jorge e os caboclos (Figura 5). Mãe Jupira, uma de nos- 
sas lideranças entrevistadas, é uma mãe-de-santo que coordena um terreno na Zona Leste de São Paulo. Ela e seu terreiro visitam o Santuário de três a quatro vezes por ano, pois todo começo de ano todos os seus filhos-de-santo que se iniciam na religião têm de passar por uma cerimônia de iniciação, a qual ela se refere como "cruza", que é um banho na cachoeira de Oxum, elemento natural presente no espaço do Santuário. Veja o que ela diz sobre a questão do domínio espiritual das ervas:

"A gente nasce de um caboclo. A primeira entidade que aparece em Terra e fala: "vamos fundar a religião de umbanda" é um caboclo. Na verdade, quem teve uma vidência na hora viu que ele tinha sido um padre na outra vida, mas ele se mostra pra gente como um caboclo, o caboclo das sete encruzilhadas (...). Como é um caboclo, ele traz essa força das matas."

Isso reflete a já citada lógica da umbanda de enaltecimento dos segmentos formadores da sociedade brasileira (negros, índios e brancos). A figura dos caboclos ("indígenas"), em especial, é bastante recorrente, pois eles representam um ponto crucial de força e de conexão com a vegetação. Além dessas duas figuras - a dos caboclos e a dos pretos-velhos -, há também várias menções às demais entidades do panteão tradicional das religiões afro-brasileiras, em especial no candomblé, com destaque para Oxóssi, orixá associado às matas e à vegetação, e às figuras que, na umbanda, são frequentemente sincretizadas à santos católicos, i.e., Ogum (São Jorge) e lansã (Santa Bárbara), que possuem no seu domínio o uso de ervas, muito citadas nas entrevistas, que são as espadas ou lanças de São Jorge/Santa Bárbara (Tabela 1; Figura 5).

Ou seja, diz-se que não existe orixá sem que existam as folhas. De fato, as folhas são elementos imprescindíveis na composição simbólica da maioria das cerimônias religiosas. As folhas são postas sob as esteiras dos iniciados durante seu período de recolhimento para Ihes prover energia, ou espalhadas pelo chão do barracão em dias de festa para que sua força se misture aos pés dos que dançam sobre elas (Figura 4). Outra possibilidade é tritura-las para compor banhos rituais (os chamados "amacis") ou produzir extratos com caráter curativo, lavando ou sacralizando um alguém ou algum assentamento.

Muitas vezes, essas ervas estão associadas às entidades através do estabelecimento das chamadas "firmezas espirituais". Essas firmezas podem ser construídas de diversas ou com as ervas frescas dispostas no chão, ou com determinados elementos vegetais secos guardados nas chamadas "quartinhas", que são potes de louça construídos para essa finalidade. Já a defumação é uma categoria de uso onde a fumaça gerada pela queima de determinada parte da erva - geralmente as folhas secas - transmitem a energia associada ao vegetal. Neste caso, a fumaça é o meio de transmissão da energia, que é absorvida pelo indivíduo pelo olfato, não através da ingestão.

A grande maioria das ervas rituais também possuem um sistema de classificação energético associado. Na umbanda, esse sistema é ou representado pelas ervas quentes/mornas/frias, ou pelas ervas fortes/fracas. Aqui exemplificamos com a explicação de mãe Antônia. Ela é mãe-pequena de um terreiro existente há dez anos oficialmente na Zona Leste de São Paulo. Ela frequenta o SANU desde criança e atualmente leva seu terreiro ao Santuário no mínimo uma vez por ano. A divisão é descrita por ela da seguinte forma:

"As [ervas] quentes são chamadas de agressivas, porque fazem a limpeza pesada. Elas são a "soda cáustica" para limpar o chão do organismo. As mornas são as equilibradoras, são aquelas que são o "paninho com álcool", que fazem a manutenção, 
o equilíbrio específico. E as específicas, que são as frias, são, como o nome diz, específicas; então eu quero uma erva pro feminino. Então tem uma erva específica pro feminino."

Ou seja, com as folhas classificam-se os deuses (e suas "qualidades") e, sabedor de suas propriedades mágicas, o sacerdote "tempera" os despachos e oferendas visando muitas vezes potencializar ou enfraquecer determinados atributos dos deuses ou características de seus filhos. Muitas entidades chegam mesmo a afirmar que com a folha "certa" podem matar ou curar (ou mesmo alterar as preferências sexuais de uma pessoa), pois existem tais ervas "quentes", que "agitam" (pertencentes aos orixás do fogo e da terra, como Ogum e Exu), e as "frias" que "acalmam" (pertencentes aos orixás da água ou do ar, como Oxum e Oxalá), como as citadas por mãe Antônia.

O sistema e classificação quente/morno/frio pode ser associado ao sistema forte/fraco. As ervas quentes são aquelas também chamadas de fortes, e as fracas são as frias ou mornas. Essa classificação, para algumas plantas, variou ligeiramente de entrevistado para entrevistado, mas ela parece ser, de alguma forma, comum entre a comunidade umbandista. Este sistema é coerente com aquele observado em outros contextos, como no candomblé, e é um sistema fundamentado em pares de oposição; o que inexoravelmente lembra àquilo apresentado por autores consagrados, como Lévi-Strauss ${ }^{17}$, onde esse nível de classificação, mesmo que desigual e arbitrário, consegue preservar a riqueza e a diversidade do inventário de plantas conhecidas. A diferença é que no candomblé, observam-se uma outra relação, compartimentando as ervas nos domínios de água/terra/fogo/ar ${ }^{16}$, enquanto que nesse estudo a divisão ficou entre a relação quente/morno/frio e forte/fraco.

\section{O Santuário ponto de permuta}

Como o SANU se insere numa unidade de conservação de proteção integral10, os frequentadores precisam trazer os elementos vegetais de fora, pois lá não é permitido a coleta de plantas para qualquer finalidade. Ou seja, muitos dos vegetais citados pelos entrevistados não consistem de ramos férteis para serem depositados em herbários, sendo muitas vezes elementos vegetais isolados (e.g., folhas, flores) ou mesmo uma mistura de elementos secos que são levados pelos religiosos para uso imediato no Santuário, onde eles realizam suas atividades.

No contexto urbano, essas plantas são geralmente coletadas ou adquiridas em locais onde há a presença destes elementos naturais: quintais, matas remanescentes em terrenos baldios ou nos fundos das casas, feiras livres, barracas de condimentos18,19, enfim, espaços onde se vendem frutas e verduras comuns no Brasil, conforme também constatado por Carlessi. São, na sua maioria, espécies exóticas, produto da relação histórico-cultural brasileira com o conhecimento europeu, africano e indígena ${ }^{20}$.

Algo importante associado ao acesso às ervas é o fato de que muitas delas são conseguidas através de contato pessoal, ou via "boca-a-boca"19. A oralidade, muito presente na umbanda e nas religiões afro-brasileiras como um todo, marca muito a construção do simbolismo associado a essas religiões. Praticamente todos os entrevistados citaram, a necessidade de se ter contatos com praticantes, além da procura de ervas seja em espaços específicos, como nas casas de ervas, seja em espaços mais gerais, como as feiras, mercados ou centrais de abastecimento de alimentos. Hoje, as feiras livres, mercados e lojas de ervas são exemplos de espaços na cidade onde se conseguem ele- 
mentos vegetais para o culto das religiões afro-brasileiras, tanto na umbanda ${ }^{7}$, como no candomblé 19,20 . No caso do candomblé, Falcão ${ }^{20}$ diz que espaços como estes descritos "medeiam um processo de socialização das diversas categorias iniciadas no candomblé, funcionando como uma caixa de ressonância dos terreiros". Aqui, pode-se dizer que o SANU cumpre exatamente esta função.

Por outro lado, os espaços de sociabilização e de transmissão de conhecimento associado às ervas tornou-se bastante restritivo e formalizado, principalmente para as gerações mais novas de umbandistas. Veja o que Mãe Rosângela diz:

"Ainda bem, hoje em dia, é muito fácil você achar as ervas. Toda casa de macumbeiro sempre tem uma ervinha plantada, né. Aqui a gente tem umas ervas plantadas. A gente toma muito cuidado onde a gente vai comprar as ervas, erva fresca, principalmente erva seca. Você vê, você passa em Pinheiros você vê um monte de lugar vendendo aquelas árvores torrando no sol, aí pega chuva... Isso não é legal. Então as frescas, tem duas médiuns aqui que vão na feira. Uma muIher que planta e colhe, traz super fresquinha... Temos o mercado da Lapa também, que tem duas bancas que fornecem... A gente tem alguns trabalhadores que tem erva em bastante quantidade em casa, que traz. Mas normalmente quando a gente vai comprar seco, a gente procura comprar, por exemplo, algumas eu compro no Mundo Verde."

Apesar de, nos últimos anos, ter havido um aumento significativo de estabelecimentos específicos para a venda de ervas e produtos vegetais próprios para o culto sagrado ${ }^{20}$, a confiança na qualidade e composição do material ainda é um questionamento para a comunidade umbandista. Por isso, muitas plantas também são cultivadas em vasos ou quintais (Figura 6), muito embora a falta de acesso a esses espaços, especialmente quintais ou jardins, é um empecilho relatado pelos entrevistados. Além disso, muitos dos entrevistados acabam passando por uma série de cursos de formação específicos para a manipulação de ervas, como aquele ministrado pelo Pai Ronaldo no SANU. Esses espaços, portanto, são importantes pois eles cumprem a função que o mencionado "boca-a-boca" tinha nas gerações mais velhas de umbandistas. Eles são basicamente espaços organizados pela comunidade umbandista para ensinar formalmente a comunidade sobre as ervas, seus significados e suas propriedades e aplicações.

Agora, independente disso, o Santuário possui essa função de ponto de permuta, e mesmo no caminho, ao longo da Estrada do Montanhão, existem muitas espécies vegetais que podem ser coletadas para logo depois serem utilizadas nos rituais, tal como diz Mãe Shirley: “Também tem muito aqui nas casas de ervas, e também uma mata aqui perto. E a gente sempre se comunicando. Porque, a ama da casa, trabalha com a linha só de ervas. Essa que dá o curso [de formação] lá em São Bernardo. É, indo pro Santuário, ali tem muito, muito mesmo. Hoje tem, como antigamente nós atravessávamos pelo teleférico. Agora a gente dá a volta. Mas ali tem tantas ervas, que o povo nem conhece."

Algumas plantas, mais difíceis de encontrar, acabam sendo, portanto, extraídas da mata, geralmente das regiões de borda de mata de áreas naturais de fácil acesso. Essas áreas de borda são justamente aquelas que estão degradadas pela ação antrópica, e contam com uma série de espécies ruderais, de crescimento rápido, justamente aquelas mais usadas na religião. Às vezes, a própria mata próxima ao Santuário é utilizada para 
essa finalidade, geralmente nas bordas da estrada que levam à entrada do Santuário (Figura 6). Os entrevistados, no entanto, não possuem o hábito de utilizar ervas da mata dentro do espaço do Santuário ou de plantas presentes no interior dessas matas. Como o Santuário está compreendido numa unidade de conservação, os órgãos públicos proíbem o desmatamento, extrativismo de ervas na mata e a realização de sacrifícios de animais. Por isso, os frequentadores trazem suas plantas de fora para o Santuário.

Ou seja, o acesso às ervas tornou-se restrito com a urbanização. Plantas que antes eram conseguidas em espaços quase naturais, ou limítrofes ao ambiente de mata, como em matas remanescentes, bordas de estrada ou terrenos baldios ou remanescentes reflorestais, agora estão cada vez mais escassos. Isso fez com que a procura pelas ervas passasse a ser mais direcionada em espaços especializados, que foram criados justamente para o fim de vender essas mercadorias:

“Erva fresca ainda tem sua essência mantida. Ela tem sua força natural ainda mantida. A seca já não, ela já passou por todo um processo de manipulação, secagem. Ela perde um pouco daquilo que a gente chama de axé, a força natural. (...) E a gente sabe que hoje se alguém pegar você tirando uma planta do meio da mata, uma planta nativa, é crime ambiental. Então a gente vai atrás de lugares que comercializam isso, acaba sendo mais difícil, e você acaba encontrando seca. Mas fresca realmente algumas são mais difíceis." (Pai Rafael em entrevista)

Portanto, as ervas secas acabam perdendo um pouco da sua energia vital, o axé, mas que, por falta de escolha, acabam por ser utilizadas, pois é a única forma de conseguir esse tipo específico de vegetal. Surgem daí as casas de ervas ou barracas especializadas em feiras livres para a venda desse tipo de material, que agora muitas vezes é seco ou desidratado, e não mais coletado fresco.
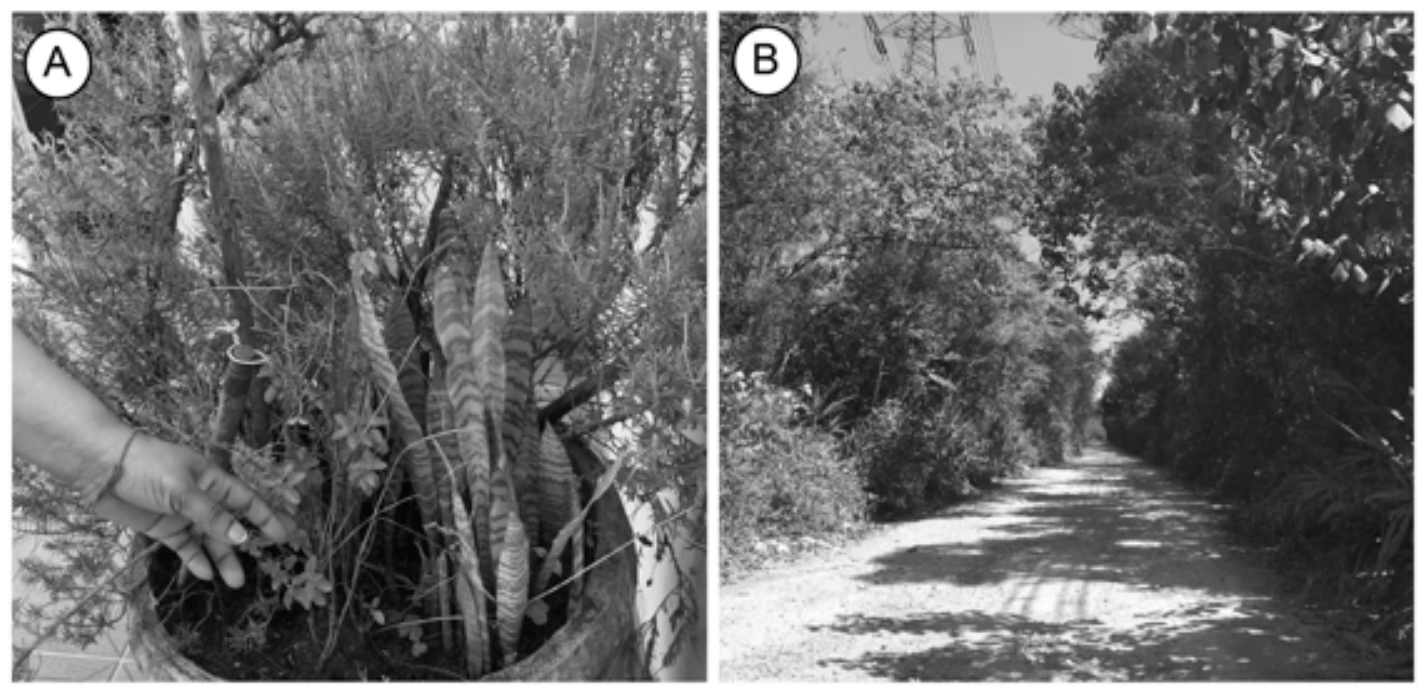

Figura 6 


\section{Considerações finais}

Tal como no candomblé, os elementos vegetais, ou as "ervas", são nucleares no desenvolvimento e nas práticas da Umbanda. Apesar dos eventuais conflitos aqui apresentados, a natureza é, acima de tudo, parte ou o todo da representação de pontos de energia, que são, por sua vez, pontos de força das entidades. Preservar as ervas, a natureza e os espaços naturais é, portanto, preservar a imagem das próprias entidades sagradas. Por isso, é muito comum que haja uma posição em prol da natureza quando se considera a relação da religião com a cidade. O culto ou apreço aos espaços naturais na umbanda, considerados como virgens ou intocados, é essencial e muito valorizado pelos seus praticantes. As plantas ali presentes, mesmo se não extraídas diretamente de uma mata para uso, são valorizadas no sentido de comporem uma vegetação íntegra, que por si só é encarada como sagrada, por ser local de moradia de entidades associadas à mata.

No entanto, este trabalho mostrou que a relação dos umbandistas com a vegetação e as ervas, mudou com o fenômeno da urbanização. O acesso ao conhecimento sagrado e prático associado às ervas ficou cada vez mais dependente de uma lógica formal, com, por exemplo, a realização de muitos cursos de formação sobre ervas. Portanto, enquanto as gerações mais antigas de umbandistas transmitiam o conhecimento associado às ervas através da oralidade, e de algo feito pela comunidade, as gerações mais novas aprendem esse conhecimento através da formalidade e via cursos, numa lógica de letramento ou de formação.

Independentemente dessa mudança, o SANU é um espaço visto como sagrado e primordial na prática da umbanda pela comunidade religiosa da Região Metropolitana de São Paulo. Ele é visto como um refúgio contra problemas de violência, segurança e até de intolerância religiosa. E não só isso: a maneira como a Umbanda trata a questão das ervas, da vegetação e da conservação da natureza faz com que o espaço do Santuário seja algo preservado, como observado no processo de recuperação da antiga área da pedreira. É, portanto, um espaço que, por ser valorizado não só por ser sagrado, mas por também ser um espaço natural, tende a se manter íntegro e por muito tempo, resguardando também o patrimônio religioso material e imaterial que faz parte da cultura e história do Brasil e do povo brasileiro.

\section{Agradecimentos}

Agradecemos a todos os membros da equipe do Santuário Nacional da Umbanda pela gentileza, apoio e carinho, em especial Pai Ronaldo e Maria Aparecida, bem como a todos os entrevistados por terem aceitado colaborar gentilmente com esta pesquisa. Por fim, agradecemos à Fundação de Amparo à Pesquisa do Estado de São Paulo (FAPESP) pelo ter financiado o primeiro autor (Processo 2016/22822-0).

\section{Referências}

1. SILVA, Vagner Gonçalves da. A criação da umbanda: História Viva. Grandes Religiões: São Paulo: Cultos Afros, 2007a, v. 6, pp. 34-39.

2. BELTRAME, Ideraldo Luiz; MARSAL, Morando. O sagrado na cultura gastronômica do candomblé. Saúde coletiva, v. 5, n. 26, pp. 242-248, 2008.

3. SILVA, Vagner Gonçalves da. Candomblé e umbanda: caminhos da devoção brasileira. São Paulo: Selo Negro, 2005, 149p.

4. VERGER, Pierre. Ewé: o uso das plantas na sociedade lorubá. São Paulo: Compa- 
nhia das Letras, 1995, 768p.

5. ULLOA-ULLOA, Carmen; ACEVEDO-RODRÍGUEZ Pedro; BECK, Stephan; BELGRANO, Manuel; BERNAL, Rodrigo; BERRY, Paul; BRAKO, Lois; CELIS, Marcela; DAVIDSE, Gerrit; FORZZA, Rafaela; GRADSTEIN, Robbert; HOKCHE, Omaira; LEÓN, Blanca; LEÓN-YÁNEZ, Susana; MAGILL, Robert; NEILL, David; NEE, Michael; RAVEN, Peter; STIMMEL, Heather; STRONG, Mark; VILLASEÑOR, José; ZARUCCHI, James; ZULOAGA, Fernando; JØRGENSEN, Peter. (2017) An integrated assessment of the vascular plant species of the Americas. Science, v. 358, n. 6370, pp. 1614-1617.

6. CAMARGO, Maria Thereza Lemos de Arruda. As plantas do catimbó em Meleagro de Luís da Câmara Cascudo. São Paulo: Humanitas, 1999, 200p.

7. CARLESSI, Pedro Crepaldi. "Nessas matas tem folhas!" Uma análise sobre 'plantas' e 'ervas' a partir da umbanda paulista. 2016. 104 f. Dissertação (Mestrado em Ciências). Universidade Federal de São Paulo, Diadema, 2016.

8. SILVA, Vagner Gonçalves da. Orixás da metrópole. São Paulo: Vozes. 1995, 325p.

9. SILVA, Vagner Gonçalves da. Intolerância religiosa: impactos do neopentecostalismo no campo religioso afro-brasileiro. São Paulo: Editora da 11 Universidade de São Paulo, 2007b, 328pp.

10. SERVICCO MUNICIPAL DE SANEAMENTO AMBIENTAL DE SANTO ANDRÉ. Plano de Manejo do Parque Natural Municipal do Pedroso: Volume I - Diagnóstico Socioambiental, 2016, 332pp.

11. VOEKS, Robert. Sacred leaves of candomblé: African magic, medicine and religion in Brazil. Austin: University of Texas Press, 1997, 256pp.

12. SERRA, Ordep; VELOZO, Eudes; BANDEIRA, Bandeira; PACHECO, Leonardo. 0 mundo das folhas. Salvador: Universidade Estadual de Feira de Santana, 2002, 237p.

13. CAMARGO, Maria Thereza Lemos de Arruda. Plantas medicinais e de rituais afro-brasileiros I. São Paulo: ALMED, 1998, 97p.

14. AZEVEDO, Sheila Karla Santos de; SILVA, Inês Machline. Plantas medicinais e de uso religioso comercializadas em mercados e feiras livres no Rio de Janeiro, RJ, Brasil. Acta Botanica Brasilica, v. 20, n. 1, pp. 185-194, 2006.

15. PIRES, Marcel Viana; ABREU, Priscilla Patrocínio; SOARES, Cynthia Silva; SILVA, Delmira da Costa; SOUZA, Brenno do Nascimento; MARIANO, Daniela Melo; LUCENA, Emerson Antônio Rocha Melo de. Etnobotânica de terreiros de candomblé nos municípios de Ilhéus de Itabuna, Bahia, Brasil. Revista Brasileira de Biociências, v. 7, n. 1, pp. 3-8, 2009.

16. BARROS, José Flávio Pessoa de. $\mathbf{O}$ segredo das folhas: sistema de classificação de vegetais nos terreiros jejê-nagô do Brasil. Rio de Janeiro: Pallas, 1993, 147p.

17. LÉVI-STRAUSS, Claude. A ciência do concreto. In: LÉVI-STRAUSS, Claude. O pensamento selvagem. 2 ed. São Paulo: Nacional, 1976.

18. STALCUP, Mary Margaret. Plantas de uso medicinal ou ritual numa feira livre no Rio de Janeiro, Brasil. 2000. 202 f. Dissertação (Mestrado em Ciências Biológicas). Universidade Federal do Rio de Janeiro, Rio de Janeiro, 2000.

19. MAIOLI-AZEVEDO, Veronica; FONSECA-KRUEL, Viviane Stern. Plantas medicinais e ritualísticas vendidas em feiras livres no município do Rio de Janeiro, RJ, Brasil: estudo de caso nas zonas Norte e Sul. Acta Botanica Brasilica, v. 21, n. 2, pp. 263-275, 2007.

20. FALCÃO, Vladimir José de Azevedo. Ewé, Ewé Ossain - Um estudo sobre os erveiros e erveiras do Mercado de Madureira: uma experiência do sagrado. Rio de Janeiro: Barroso Edições, 2002, 167pp. 